\title{
ملامح الفكر التربوي عند الإمام البخاري: \\ قراءة تحليلية لكتاب "العلم" من "الجامع الصحيح"
}

* علي إبراهيم سعود العجين

الملخص

يوضح البحث مفهوم الفكر التربوي عند الإمام البخاري من كتاب العلم من الجامع الصحيح، كاشفاً عـنـ

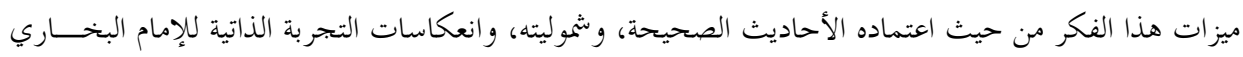

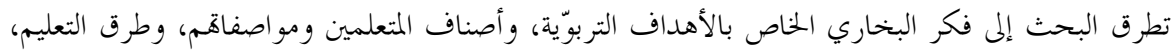

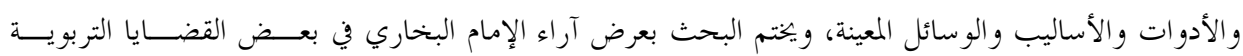

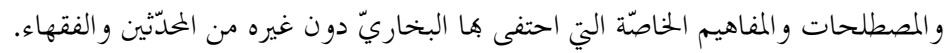

الكلمات المفتاحية: الفكر التربوي، الإمام البخاري، الجامع الصحيح، كتاب العلم.

Features of Imam al-Bukhari's Educational Thought: Analytical Reading of "Knowledge" Chapter of al-Jami' al-Sahih

\begin{abstract}
This paper elaborates on educational thought of Imam al-Bukhari as relayed in the chapter on Knowledge of his book al Jami' al-Sahih. It reveals features of thought, namely: its comprehensiveness, relying on sound Hadiths, and the implications of alBukhari's personal experience with it.

The paper addresses al-Bukhari's thought relating to educational goals, types of learners, teaching methods, and supporting tools and means. It concludes with alBukhari's views on some educational issues, terms, and educational concepts that he, in particular, has given attention to.
\end{abstract}

Key words: Educational thought, Imam Al-Bukhari, al Jami' al-Sahih, Book of Knowledge.

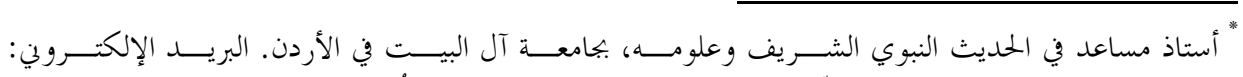
aliajeen@yahoo.com 
مقدمة:

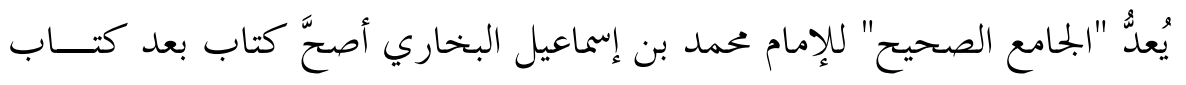

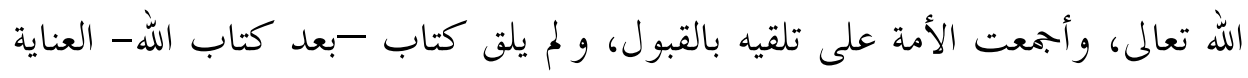

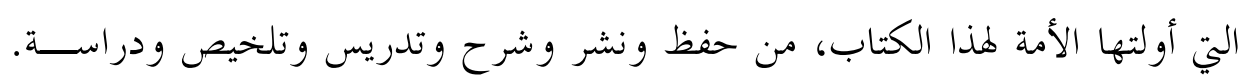

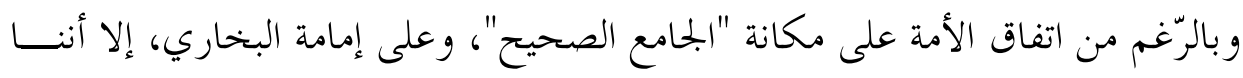

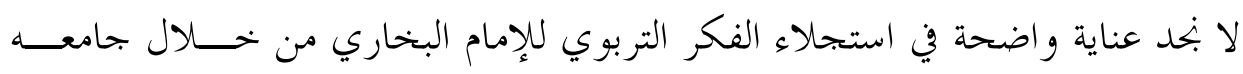

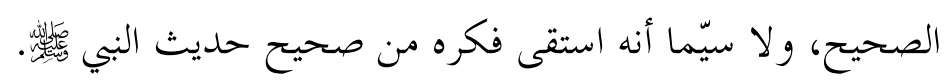

وتأتي هذه الدراسة لتجلية الفكر التربويّ لدى هذا الإمام الجليل، والبحث في آراء

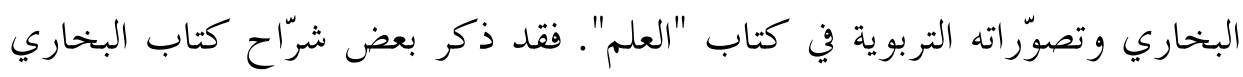

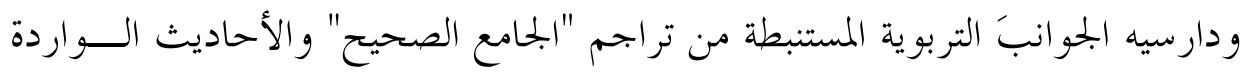

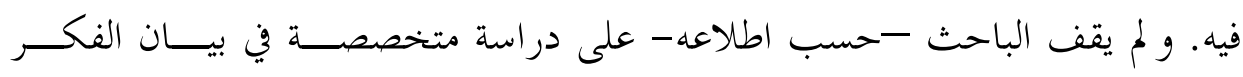

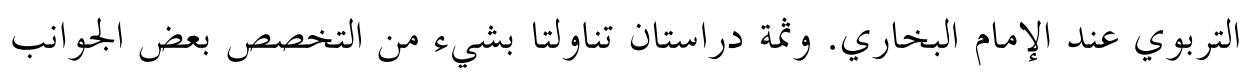

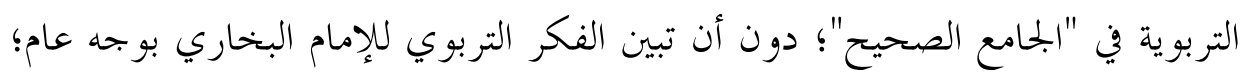

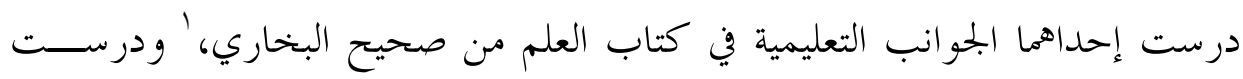

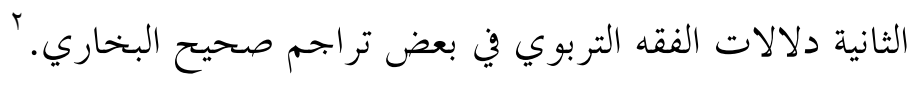

أولاً: الفكر التربوي عند الإمام البخاري: مفهومه ومصادره وميزاته

\section{ا ـ مفهوم الفكر التربوي عند الإمام البخاري:}

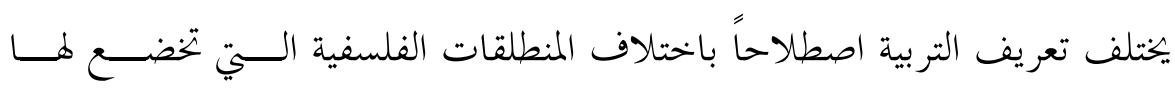

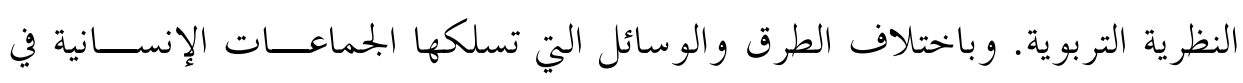

' الطوالبة، إبراهيم عمد. الجوانب التعليمية في كتاب العلم من صحيح البخاري، رسالة ماجستير غير منشورة،

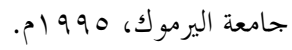
r العليمي، أحمد عحمد. دلالات الفقه التربوي في بعض تراجم صحيح البخاري، بيروت: دار ابن حسزم، طا، 
تدريب أجيالها وإرساء قيمها ومعتقداها. وباختلاف الآراء في مفهوم العملية التربويسـة وطرقها ووسائلها.

و التربية الإسلامية هي: "المفاهيم و القيم والأساليب و الاتحاهات المتضمنة في آيات

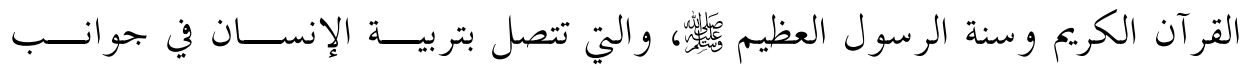
شخصيته المختلفة." شعر و

أما الفكر فهو "عمل الذهن تدبُّاً و تأمُّلاً في أي شأن من شؤون الحياة الــدنيا أو الدين. وهو نشاط بشري أداؤه العقل، وثمراته الرأي و العلم و المعرفة."

وعلى ذلك فإن على الباحث -الذي يجهد نفسه في سبيل بيان موقــف التربيــة

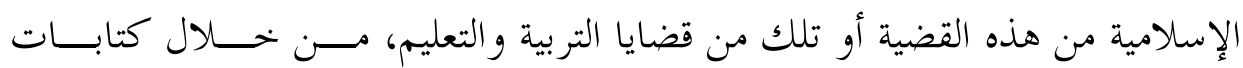
المفكرين - أن يصحح عبارته وينسب الموقف إلى العالِم الذي يذرِســه، أو المدرســـة الفكرية التي يبحث في فكرها. فالقول بأن موقف التربية الإسلامية هو موقف هذا أو

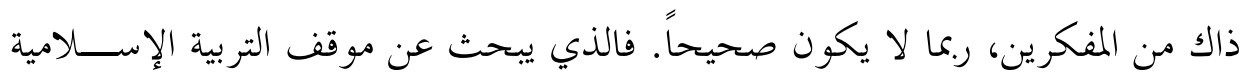
من قضية ما، عليه أن يتجه مباشرة إلى مصدري الإسلام الأساسيين وهمـــا: القـــــآن الكريم و السنة المطهرة.

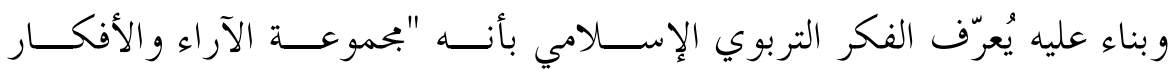
و النظريات التي احتوها دراسات الفقهاء و الفلاسفة والعلماء المسلمين، وتتصل اتصالاً

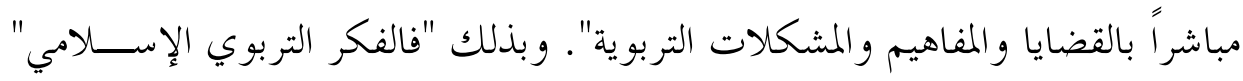
هو رؤية العلماء المسلمين وتفسيراتهم للتربية الإسلامية. ل

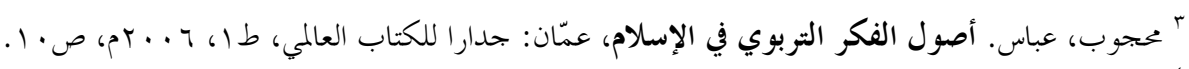

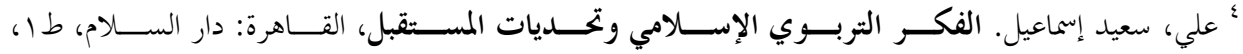

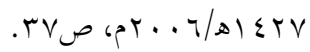

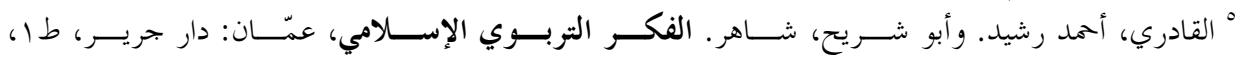

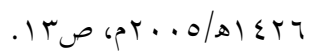

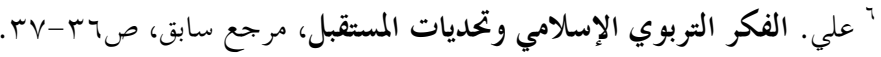

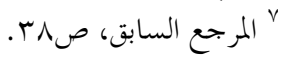


وبهذا يكون الفكر التربوي المقصود في هذه الدراسة، عنـــــ الإمـــام البخــــاري:

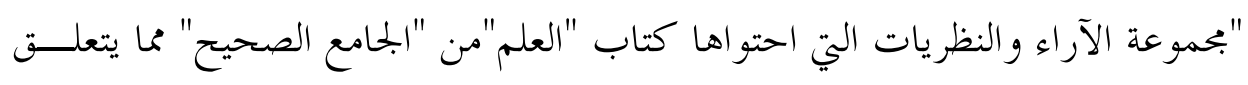
بالقضايا والمفاهيم والمشكلات التربوية". و إنما ذكرنا كتاب "العلم" لأنه الميدان الأصيل

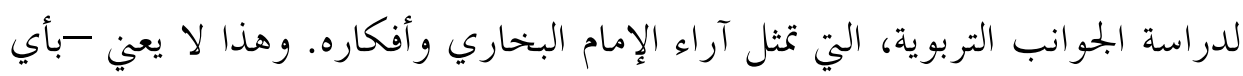
حال من الأحوال- أن الفكر التربوي للبخاري يقتصر على ذلك، ولكن كتون كتاب العلم يعكس ملامح هذا الفكر بشكل و اضح أكثر من غيره.

فعلى سبيل المثال، بَّوب البخاري أحد أبواب كتابه بــ: "باب: من سئل علمــــاً

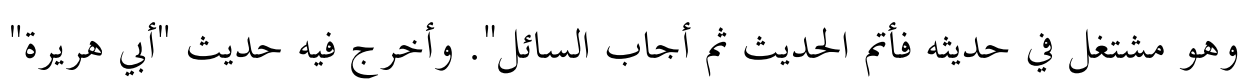

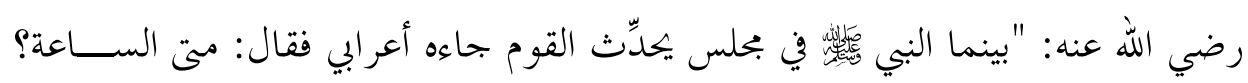

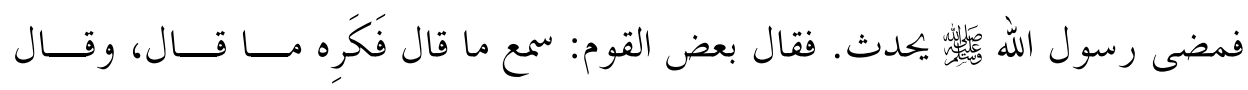
بعضهم: بل لم يسمع. حتى إذا قضى حديثه قال: أين أراه السائل عن الساعة؟ قال: ها فال

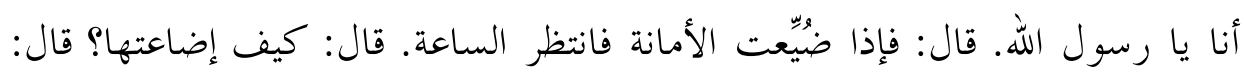

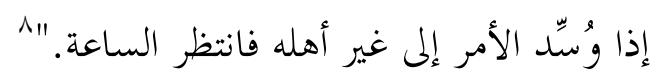

قال ابن حجر تعليقاً على هذا الحديث: "معصلة التنبيه على أدب العَالِم والمــتعلمّم،

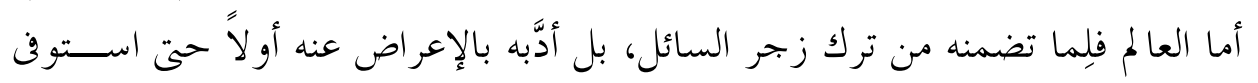

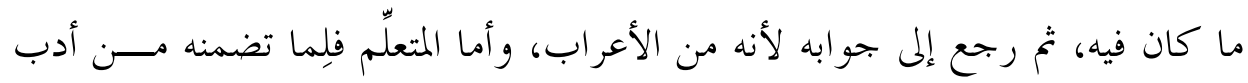

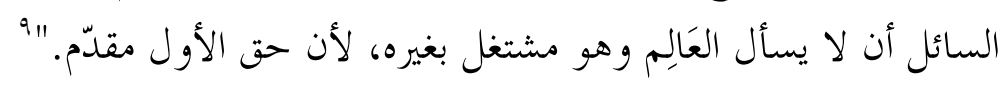

\section{Y. مصادر الفكر التربوي عند الإمام البخاري:}

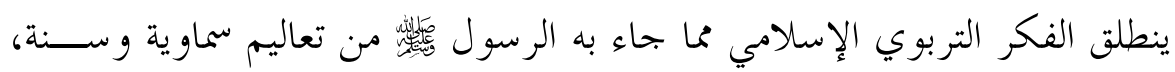

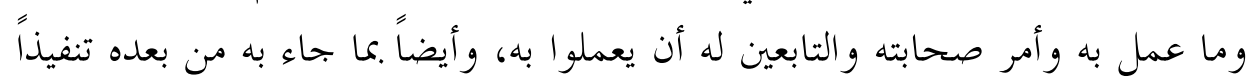

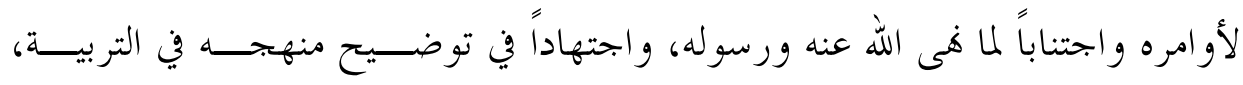

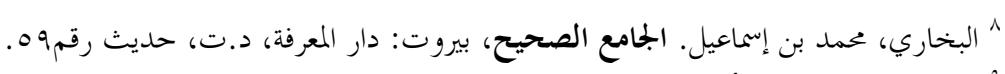

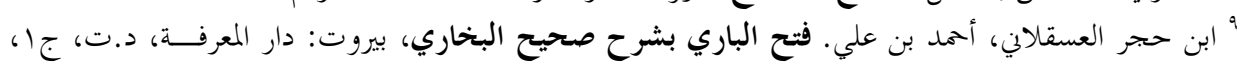


وأسلوبه في المعاملة، الذي انطلق من تربية سماوية روحية وجسدية، كانت وما تــزال منهج عبادة ومنهج فكر ومنهج عمل. '.

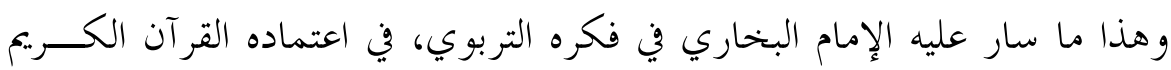

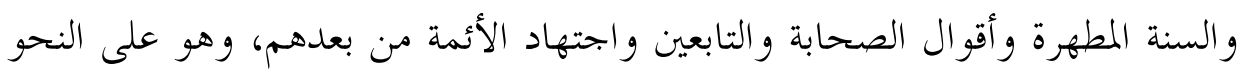
الآتي:

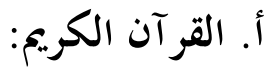

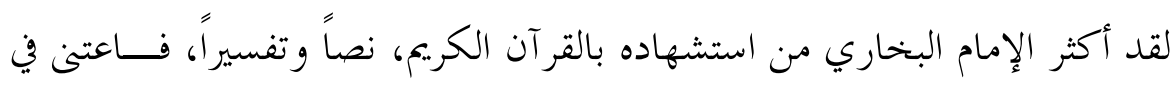

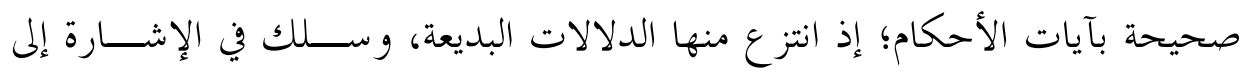

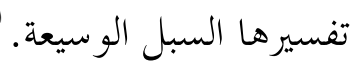

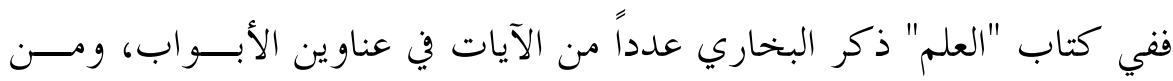
ذلك:

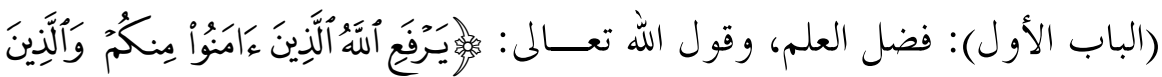

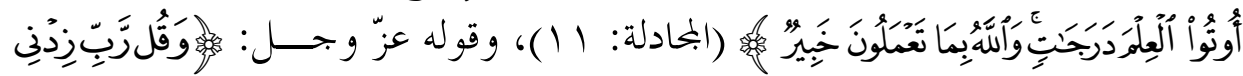

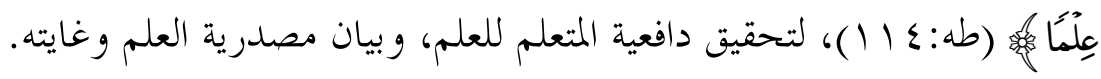

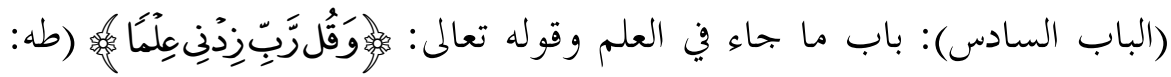

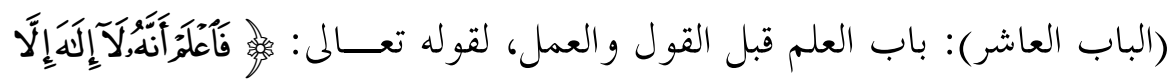

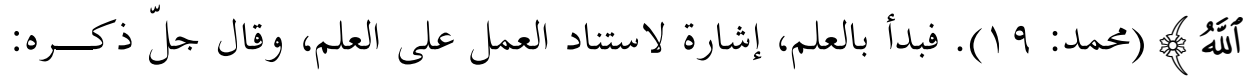

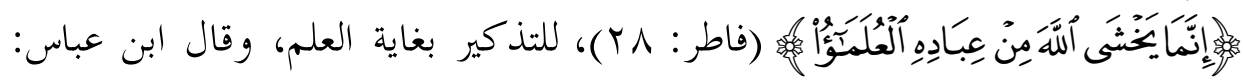

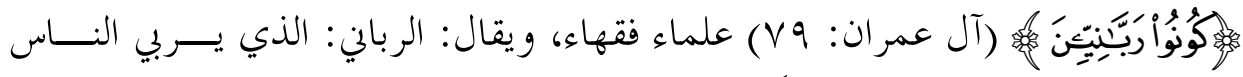

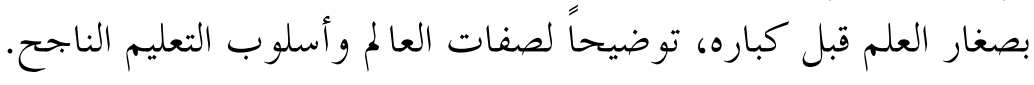

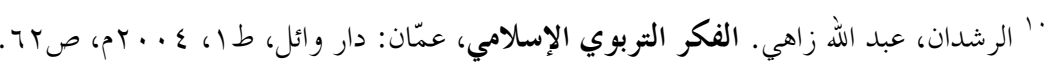

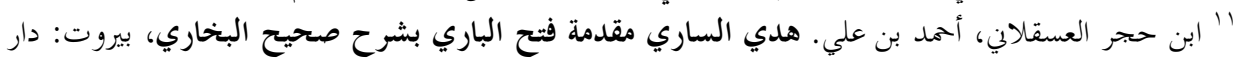

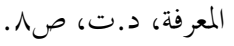




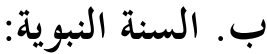

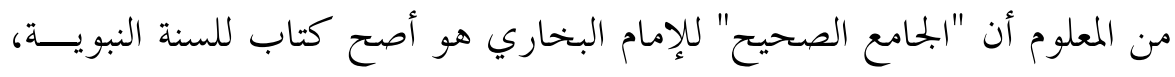

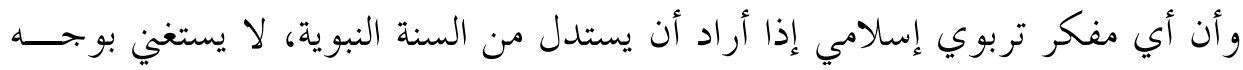

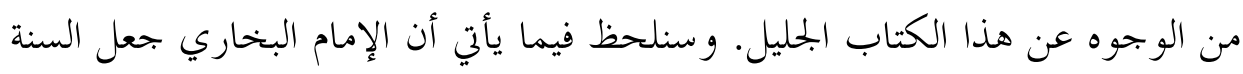

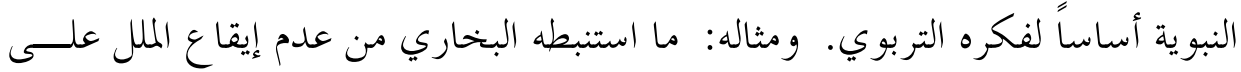

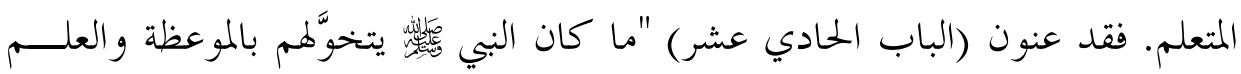

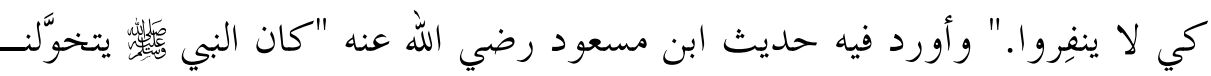

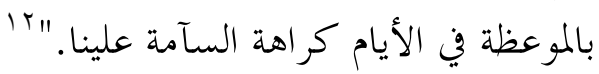

ت. أقوال الصحابة رضو ان الله عليهم:

أودع الإمام البخاري أقو ال الصحابة في عناوين كتابه، واستدل منها على آرائسـه.

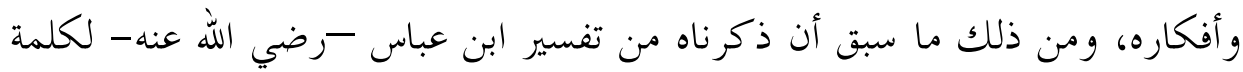

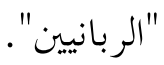

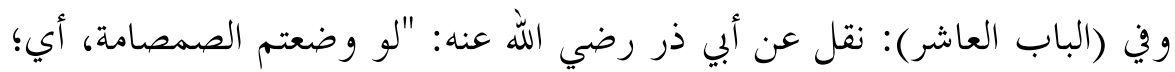

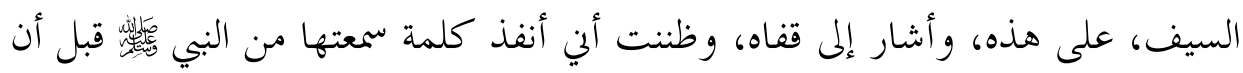

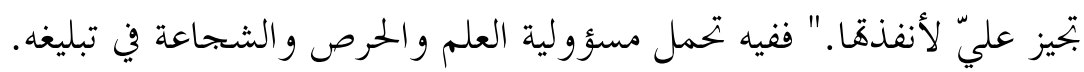

أمّا (الباب الخمسون) فخصّصه لموضوع: الحياء في العلم، و نقل فيه عن عائشسـة

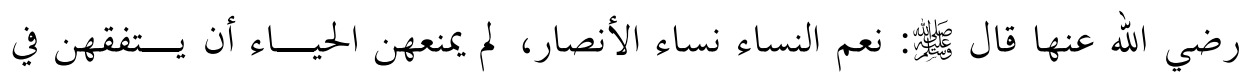

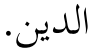

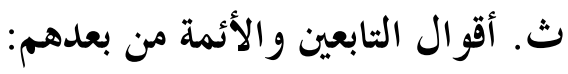

ومن ذلك ما نقله عن بحاهد في (الباب الخمسون): الحياء في العلـــم: "لا يــتعلم

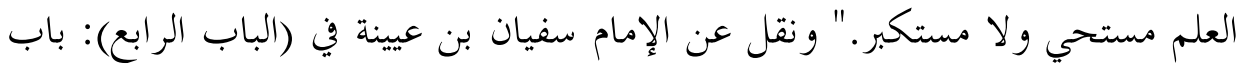

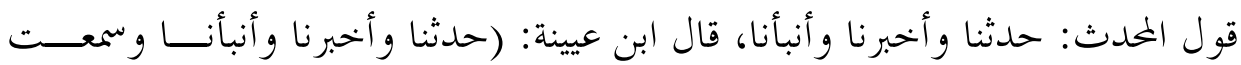




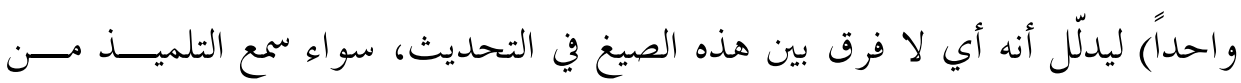
الشيخ أو قرأ عليه.

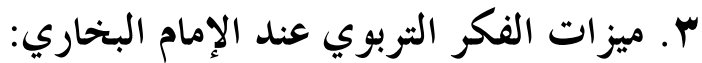

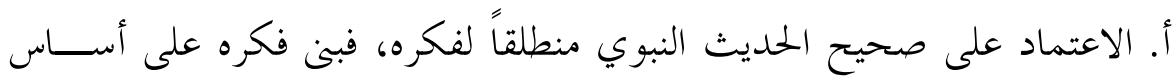

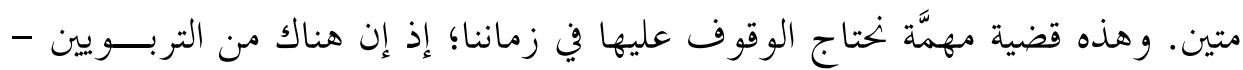

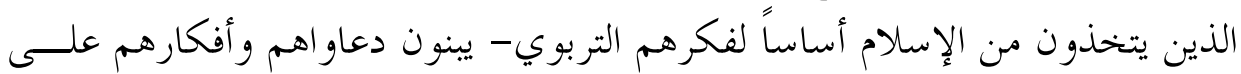

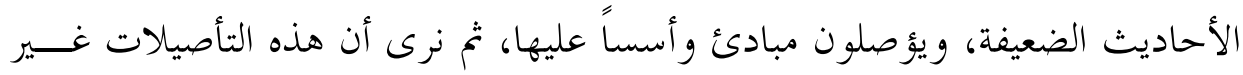

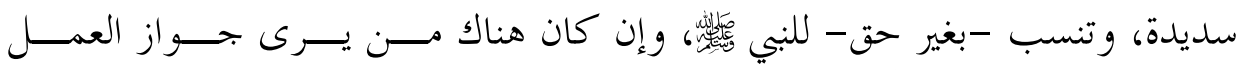

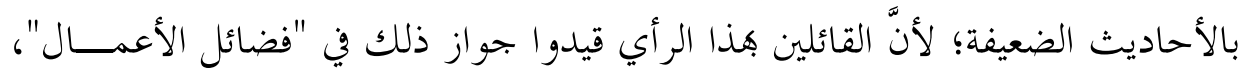

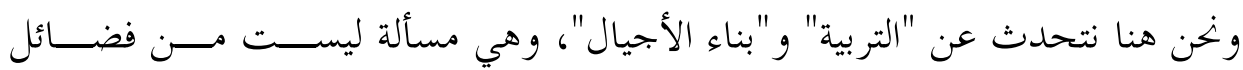
الأعمال، بل هي جوهر الأعمال.

ب. يعد "الفكر التربوي" للإمام البخاري، وليد بتربة تربوية حافلــة، مارســها

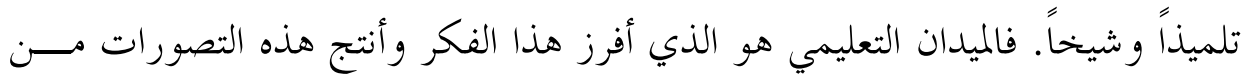

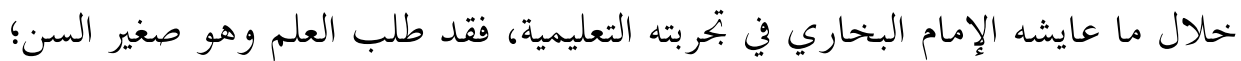

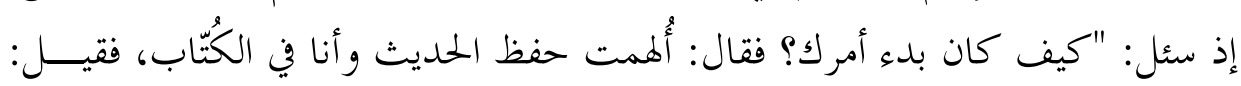

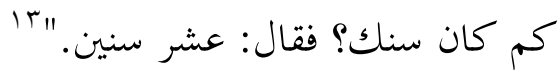

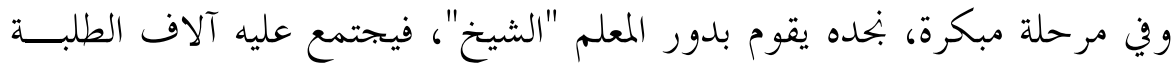

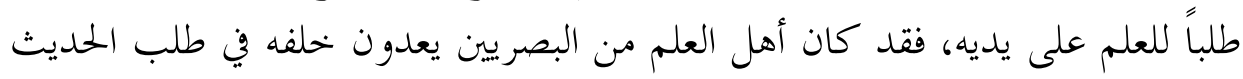

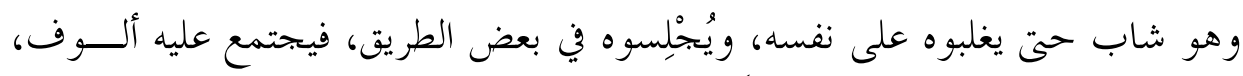

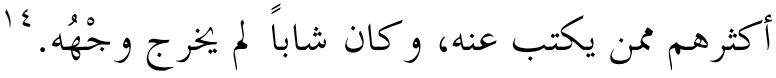

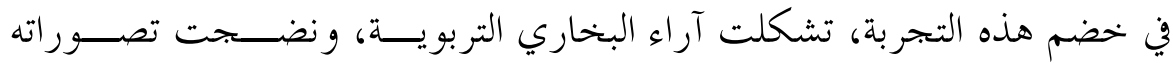

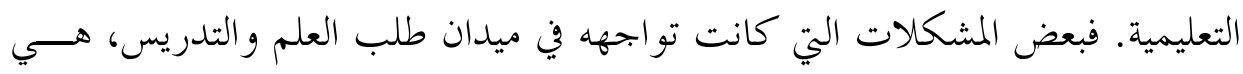

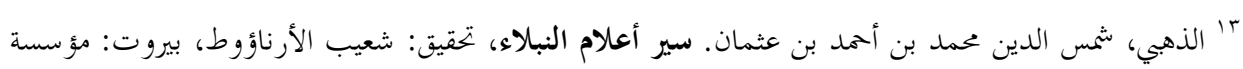

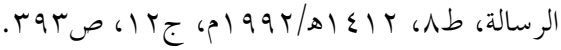

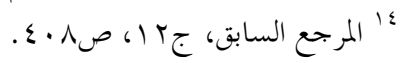


التي كوّنت "فكره التربوي". و هذا ما نلمحه في تبو يباته وعناوينه في كتاب "العلـــم".

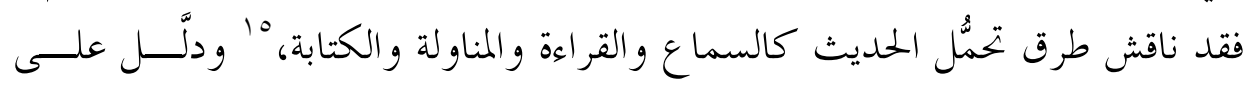
مشروعيتها من السنة النبوية. كما ذكر موضوع تحمّل الصغير للحديث هل هو صــحيح أم لا، وأدرجــه في

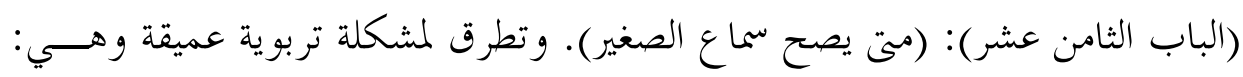

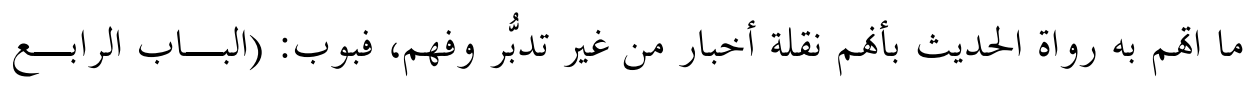

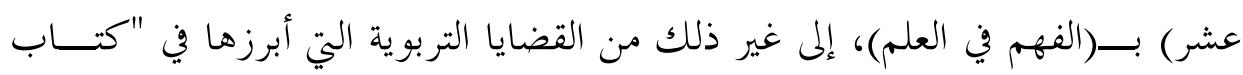

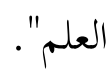

ت. ومن ميزات الفكر التربوي لإِمام البخاري شموليته وترابطه؛ فالقضايا التربوية التي ناقشها الإمام البخاري، شاملة لكل جوانب العملية التعليمية بتر ابط محكم بين كل

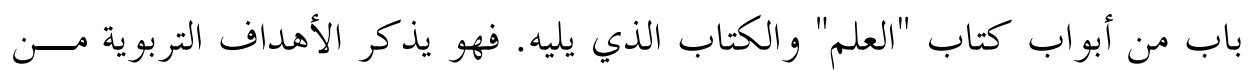
خلال ما بدأ به وهو (الباب الأول): "فضل العلم"، تم ينتقل إلى آداب العلم فيبوب بهاب (الباب الثاني): "من سئل علماً وهو مشتغل في حديثه"، ثم يتحدث عن البـ البيئة التعليمية الناجحة، وذلك من خلال (الباب الثالث): "من رفع صوته بالعلم". و وفي هذه الأثنــاء

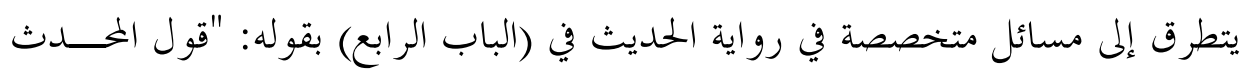

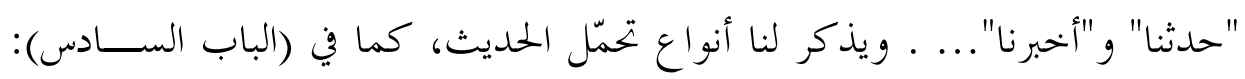
"القراءة و العرض على المحدث" ونحوها، ثم يعود لذكر آداب العلم وأصناف المــتعلمين

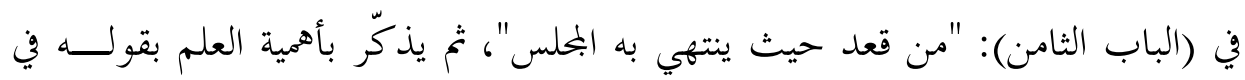
(الباب العاشر) "العلم قبل القول و العمل" فئل

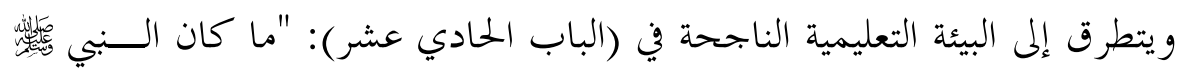
يتخولهم بالموعظة والعلم كي لا ينغِروا". و يتناول: أوقات التعليم في (البـــاب الثـــاني

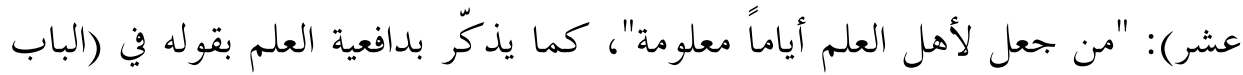

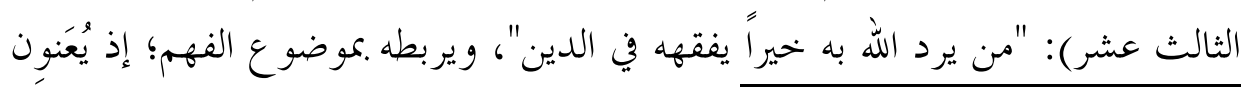

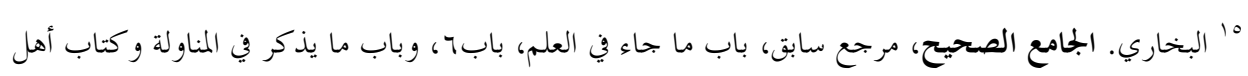


(الباب الرابع عشر) بـــ: "الفهم في العلم"، ثم بحاجة طالب العلم للرحلـــة في طلبــــ

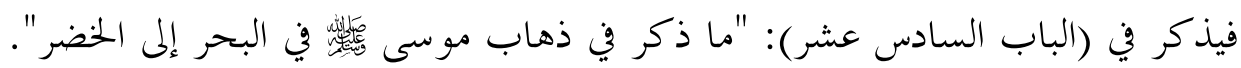

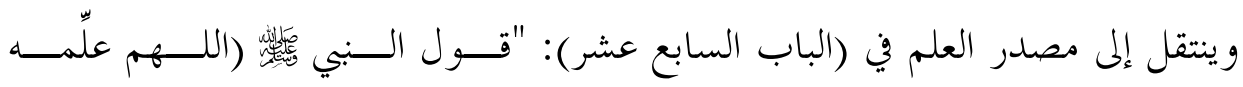
الكتاب).

ويخصص (الباب الثامن عشر) لتعليم الصغار: "متى يصح سماع الصغير"، ويعــود

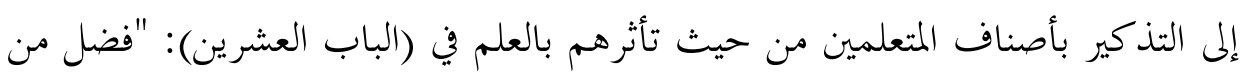

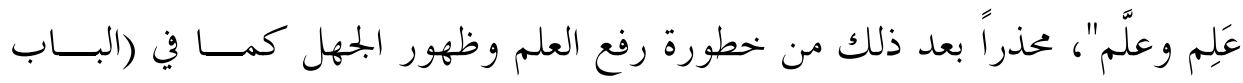
الحادي و العشرين): "رفع العلم وظهور الجهل ". ثم ينتقل إلى الوسائل التعلمية بقوله في

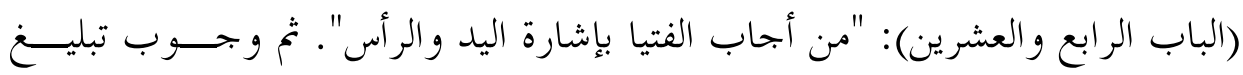

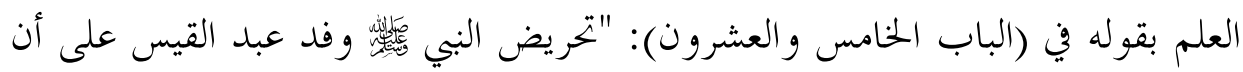

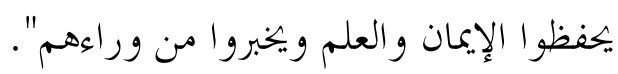

و ينتقل إلى (الباب السابع و العشرين): "التناوب في العلم"، وهو مصطلح تربـــوي

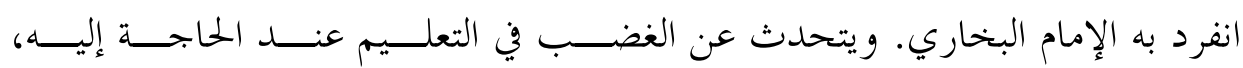
فيقول(الباب الثامن والعشرين): "الغضب في الموعظة و التعليم إذا رأى ما يكره". و وبعد ذلك ينتقل إلى موضوع تعليم المرأة بقوله في (الباب الحادي و الثلاثين): "تعليم الرجل

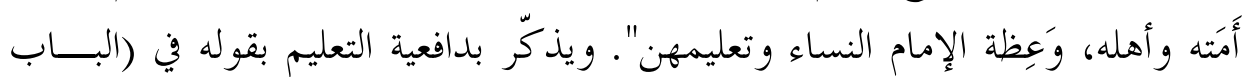

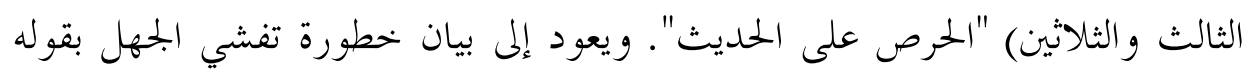

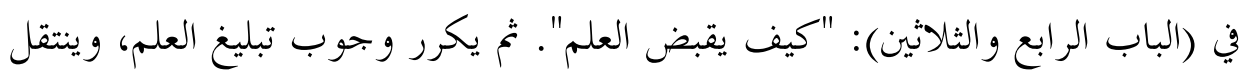

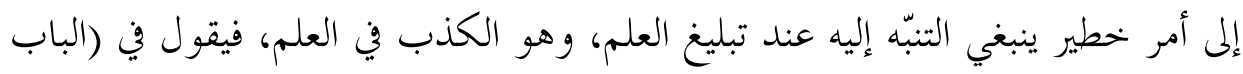

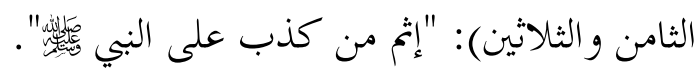
وحتى لا يقع في الخطأ والكذب في العلم يذكر أدوات العلم، فيقول في (البــاب

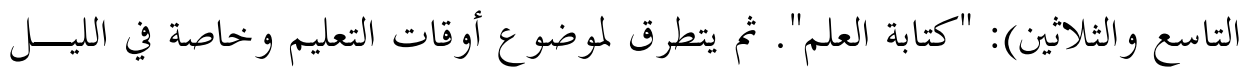
فيذكر في (الباب الأربعين): "العلم والعظة بالليل". ويؤ كد على أدوات العلم بقوله في

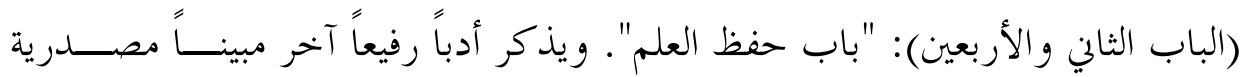




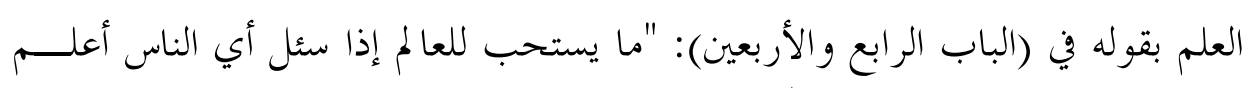

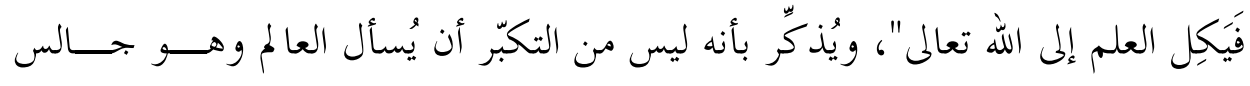

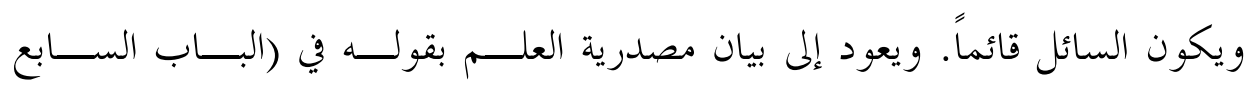

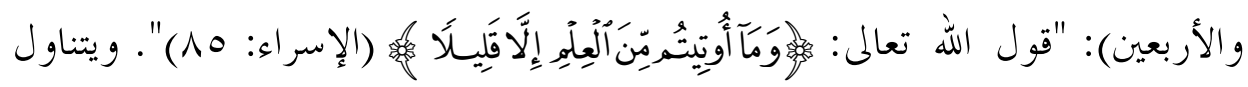

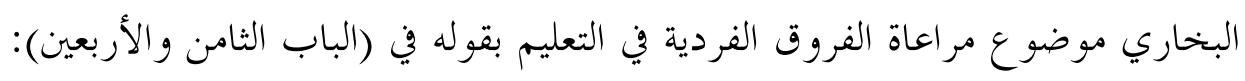

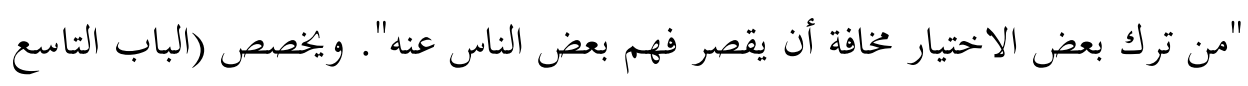

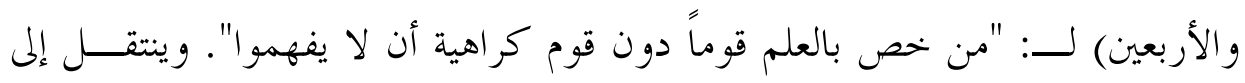

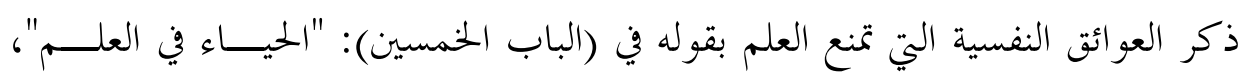

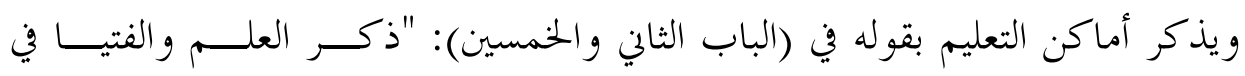

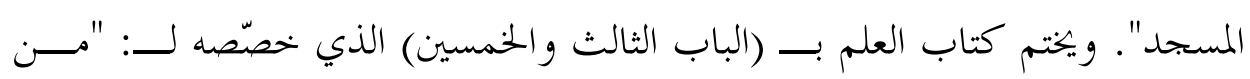

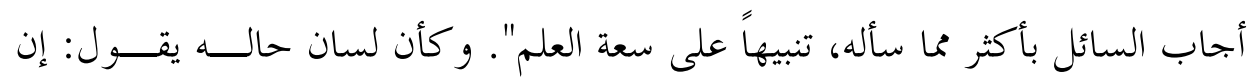

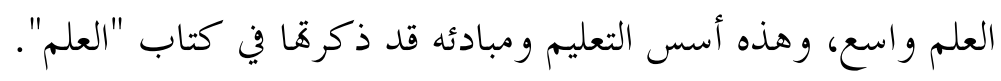
ومما سبق من بيان مصادر الفكر التربوي عند البخاري وميزاته، يتبين لنا انتمـــاء

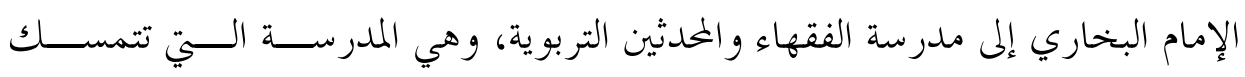

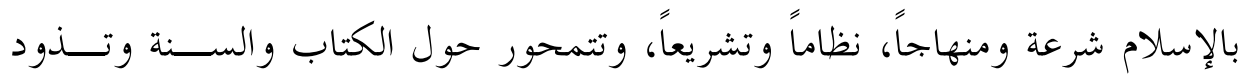

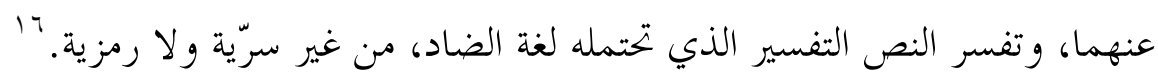
ولقد مرت هذه المدرسة بمر حلتين؛ الأولى: مرحلة الاتفاق بين المحدثين والفقهـــاء

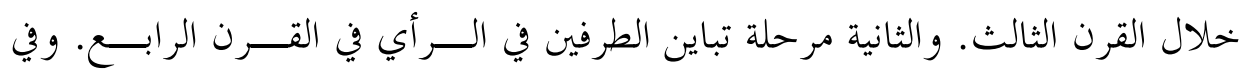

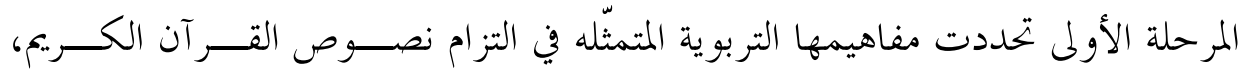

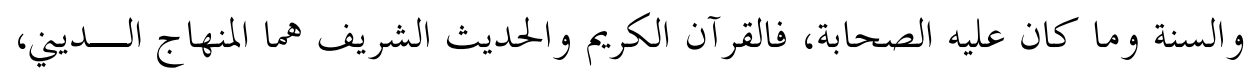

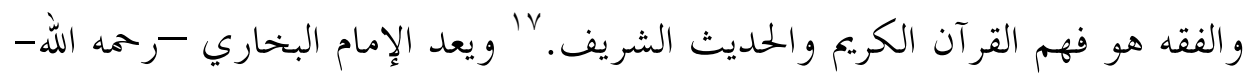

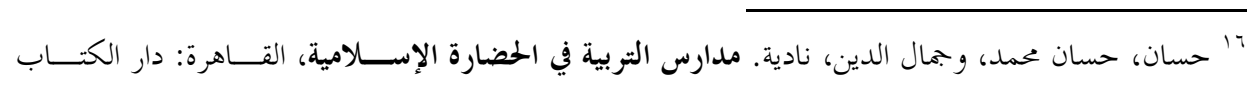

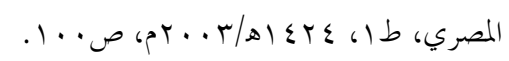

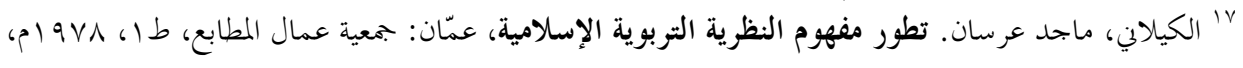




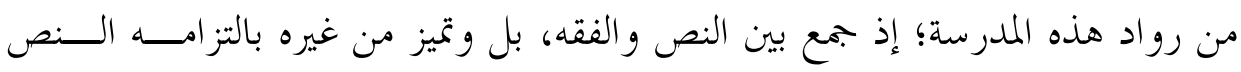
الصحيح من السنة النبوية، ودقة استباطه الفقهي.

\section{ثانياً: الأهداف التربوية في فكر الإمام البخاري}

رسم الإمام البخاري أهدافه التربوية من منطلق توحيد الله تعالى، فبوّب (البــاب

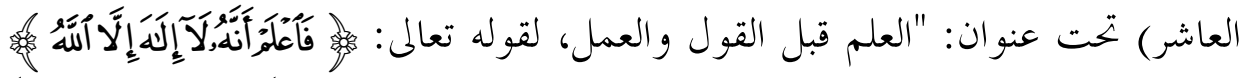

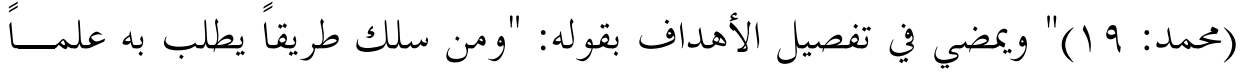

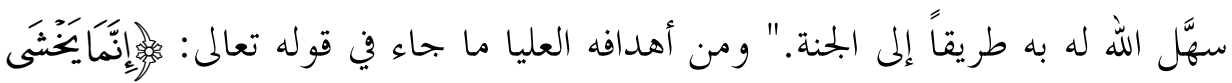

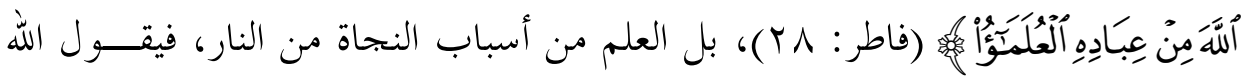

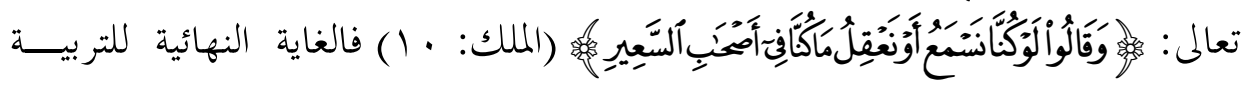

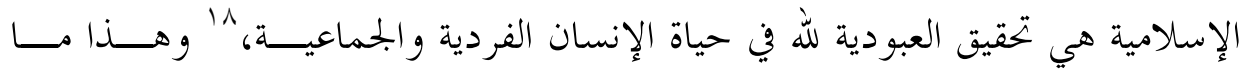

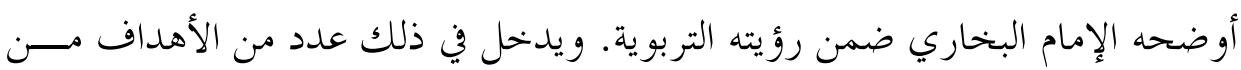
أهمها:

ا. العلم أساس في صحة القول والعمل: جعل البخاري (الباب العاشر) بعنــــان:

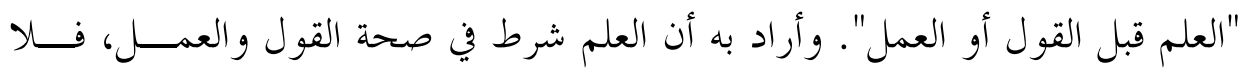

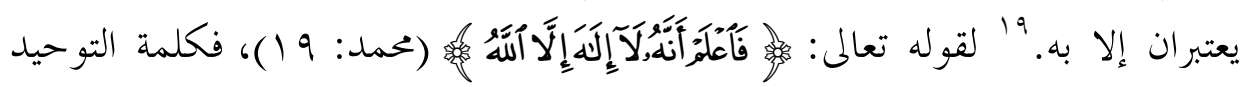
لا تُقبل بغير العلم.

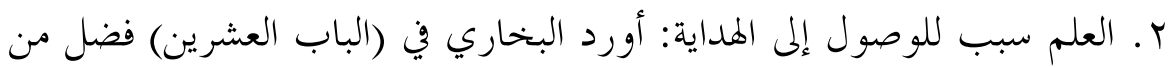

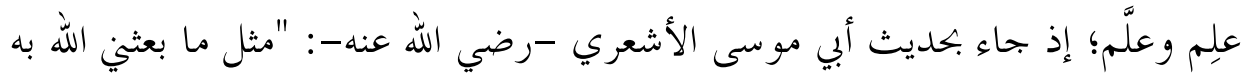

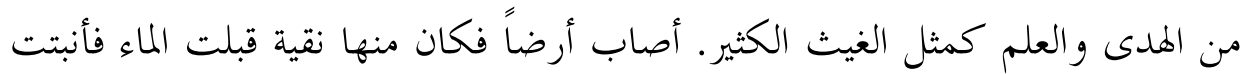

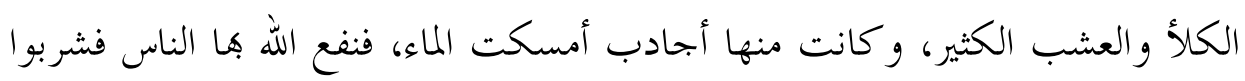

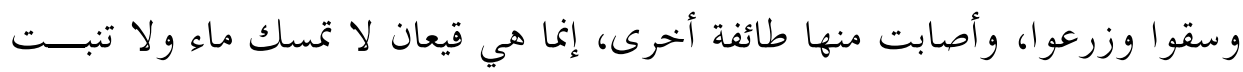

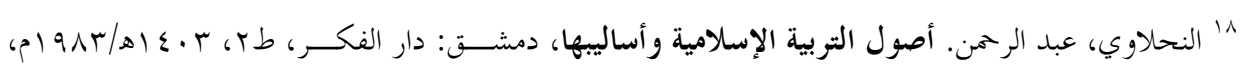
ص1.1. 19 ابن ححر، . فتح الباري بشرح صحيح البخاري، مرجع سابق، ج1، ص1 ا. 


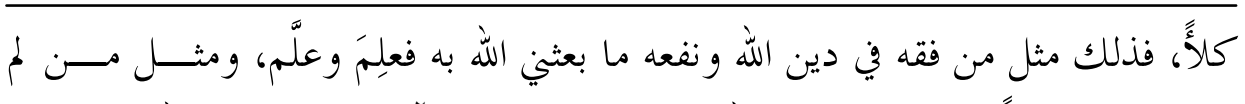

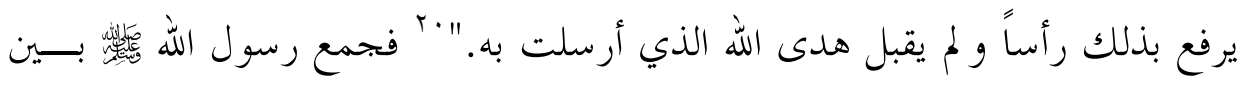

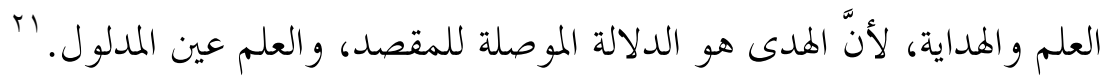

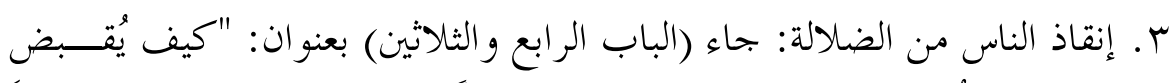

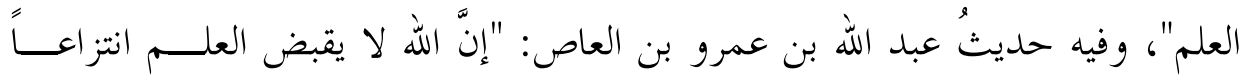

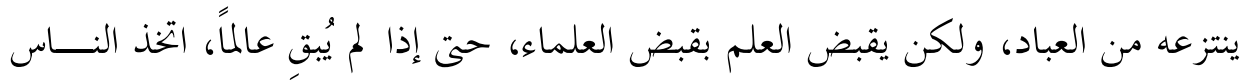

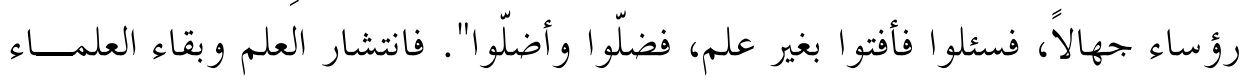
يمنع من الوصول إلى هذه النتيجة: "فضلّو ا واضلّوّا".

ع. تحقيق الخيرية والسمو والرفعة للإنسان: جعل البخاري (الباب الثالث عشــر )

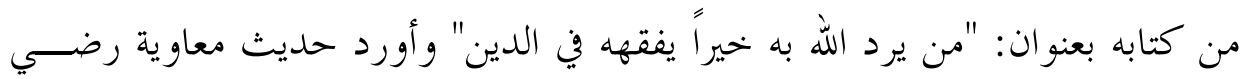

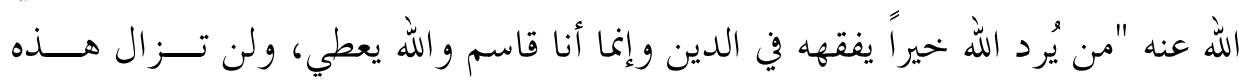

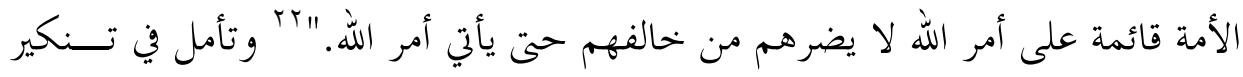

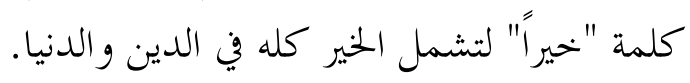

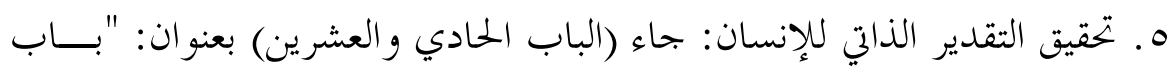

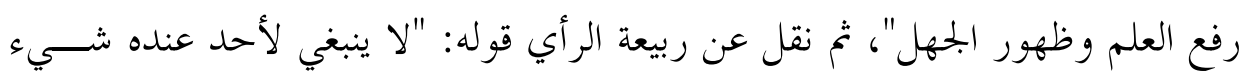

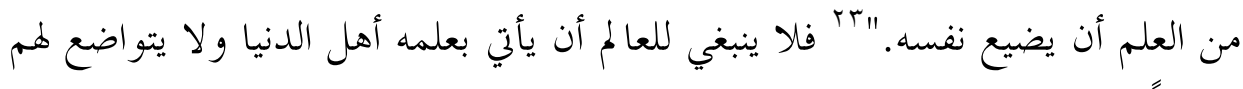

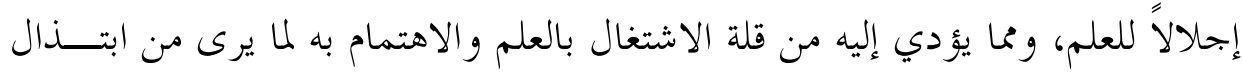

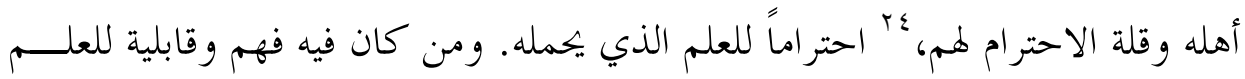
لا ينبغي له أن يهمل نفسه، فيترك الاشتغال بالعلم، لئلا يؤدي ذلك إلى إلى رفعه.

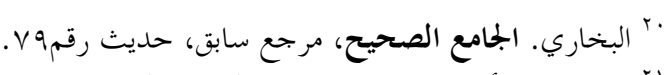

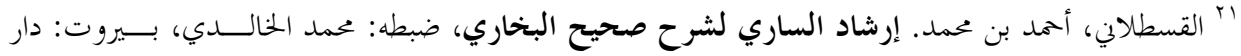

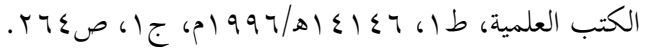

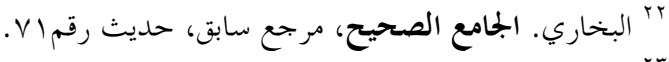

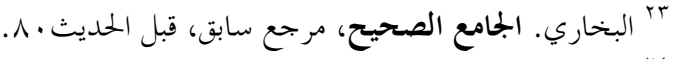

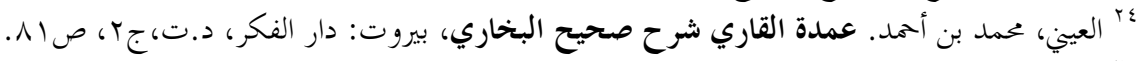

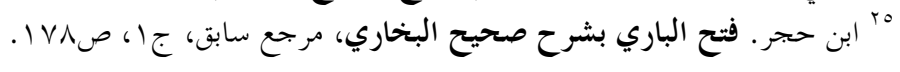


جـ التربية العقلية: كما اهتم الإمام البخحاري بالبعد الديني للتربية، اعتى بالبعــــ

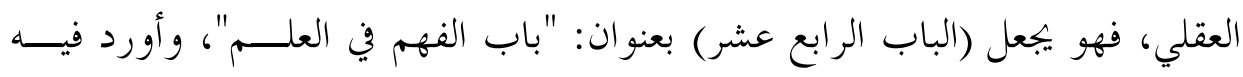

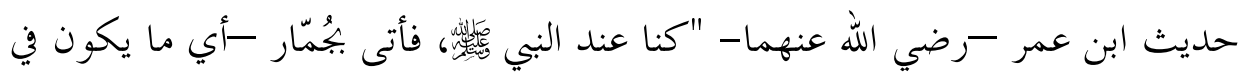

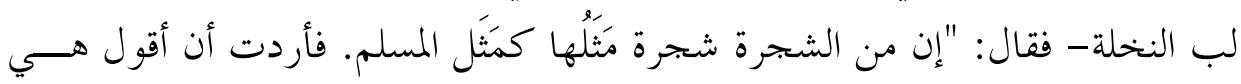

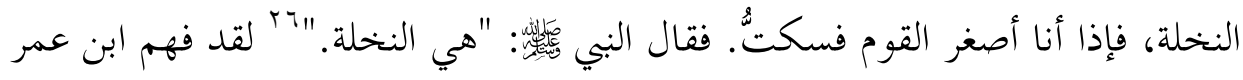

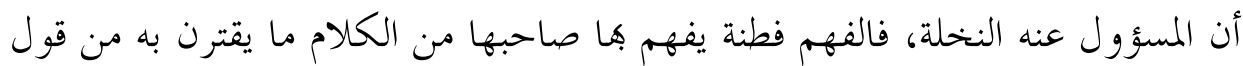

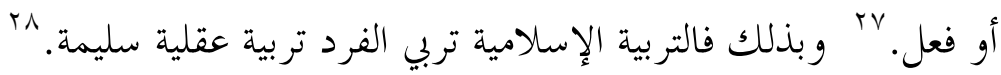

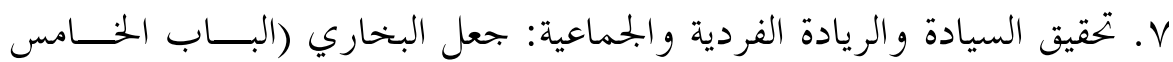
عشر) بعنوان: "الاغتباط في العلم و الحكمة"، وأورد فيه قول عمر رضــي الله عنـــه: (تفقهوا قبل أن تسودوا) قال البخاري: (وبعد أن تسودوا)، قال ابن المنيّر: "مطابقـــة قول عمر للترجمة أنه جعل السيادة من ثمرات العلم، وأوصى الطالب باغتنام الزيـــادة قبل بلوغ درجة السيادة، وذلك يحقق استحقاق العلم بأن يغبط صاحبه، فإنه ســبب

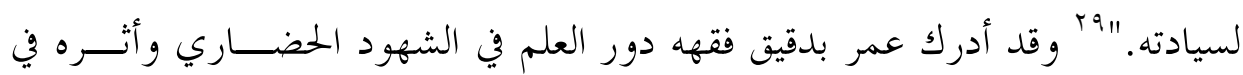
سيادة الأفراد والأمم وتقدمهم على الآخرين، وهذا هو سر تقـــدم الغـــرب في شــتى الميادين، فما سادوا الأمم إلا بالعلم.

ثالثاً: مو اصفات المربي و آدابه عند الإمام البخاري لا تنفك صفات المربي المسلم عن أهداف التربية الإسلامية التي تسعى لتحقيقهــا،

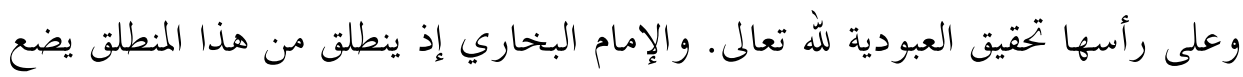

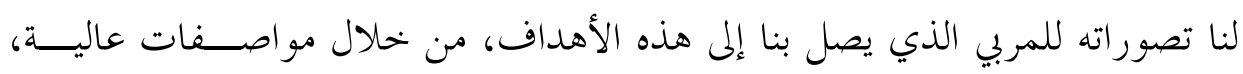
وآداب رفيعة يلزم المربي أن يلتزم هـا وهي:

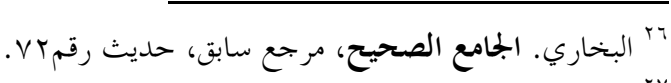

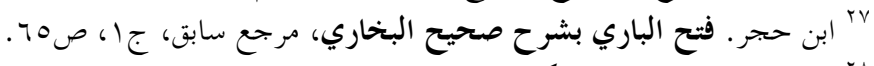

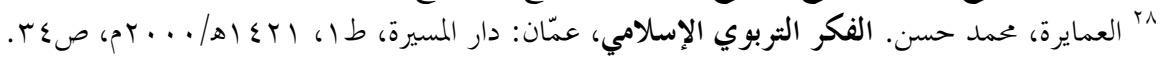

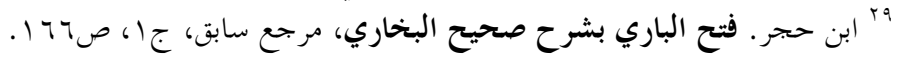




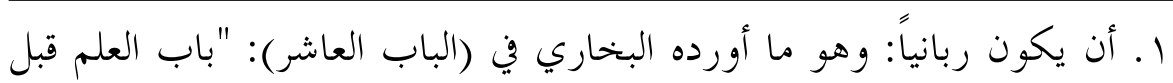

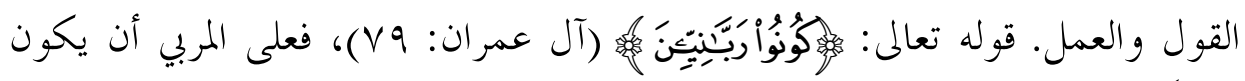

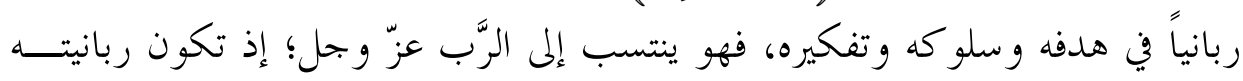

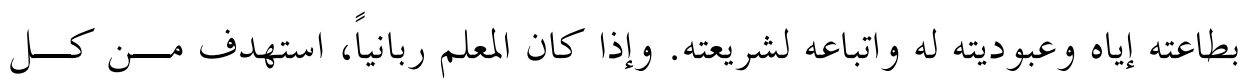

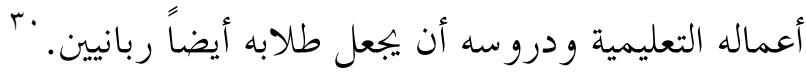

r. اتصافه بالعلم: وهذا ما أكده البخاري في (الباب العاشر): "العلم قبل القـــول

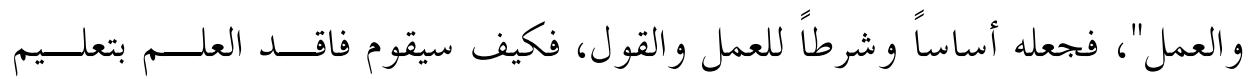

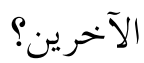

r. الصبر والرفق: خصص البخاري (الباب الثاني) للحديث عن: (من سئل علماً

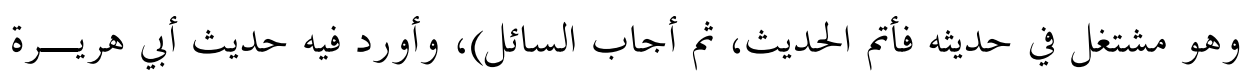

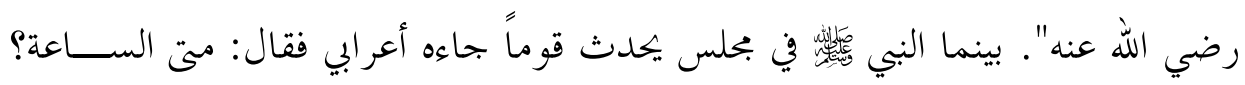

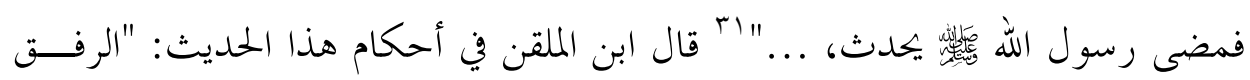

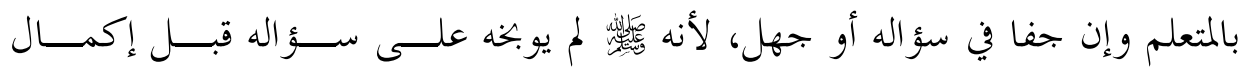
حلديثه.

ع. التيسير والتبشير: ونوّه إليه البخاري في (الباب الحادي عشر): "ما كان البي

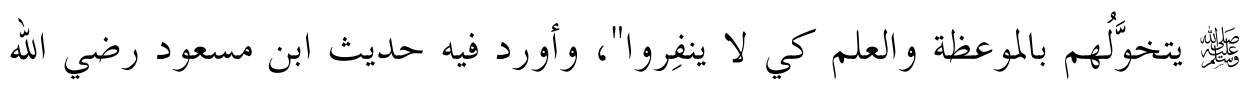

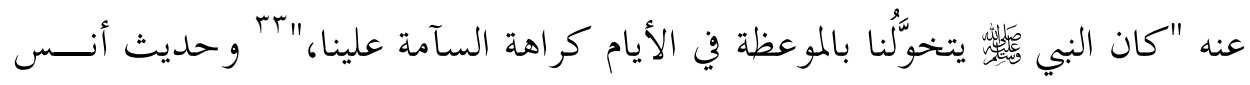

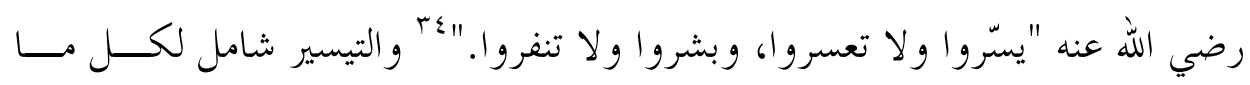

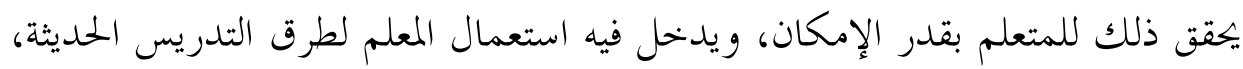

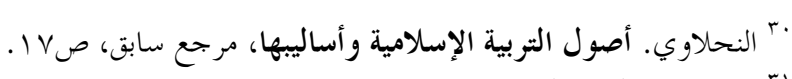

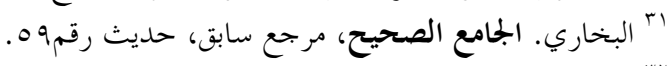

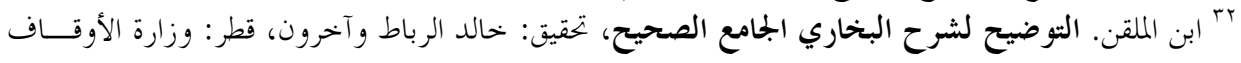

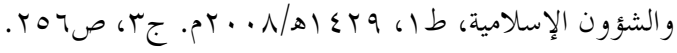

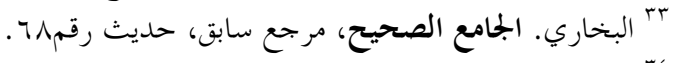

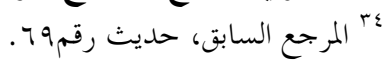




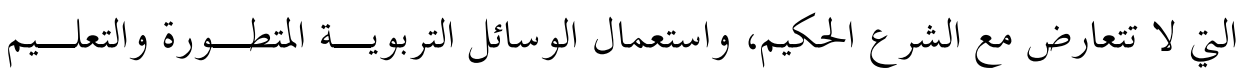

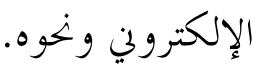

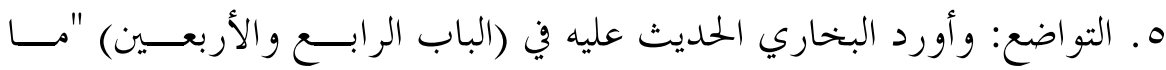

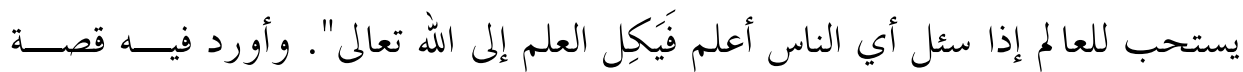

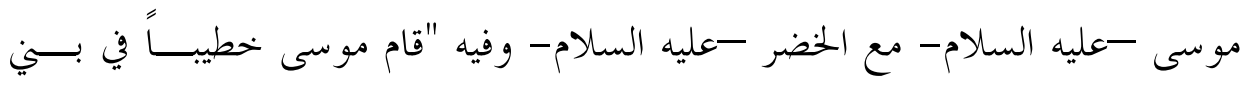

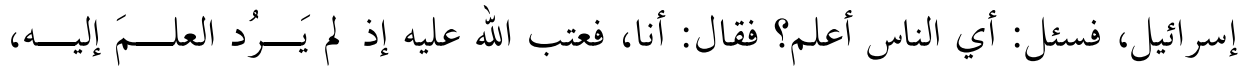

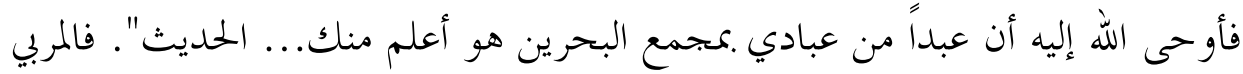

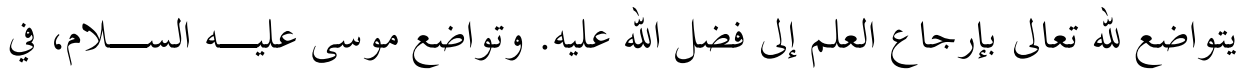

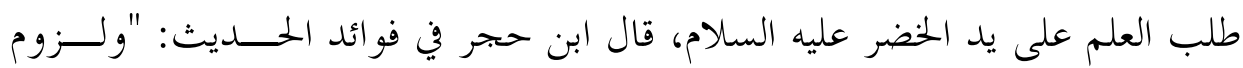

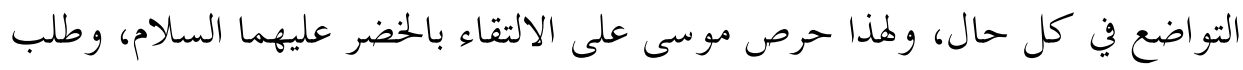

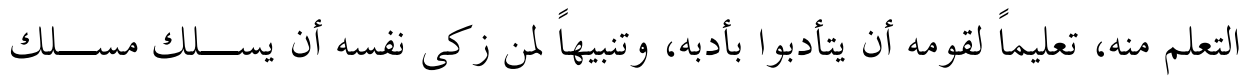

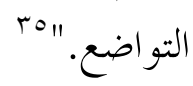

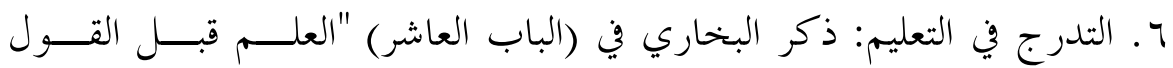

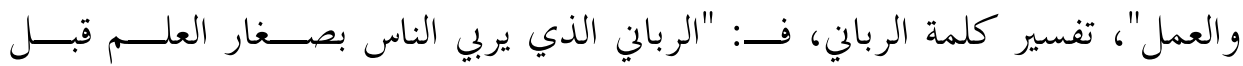

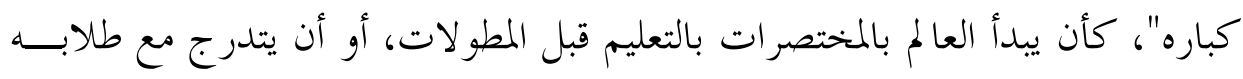

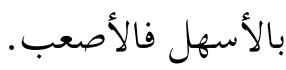

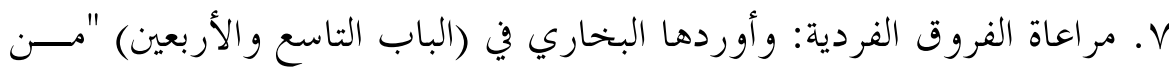

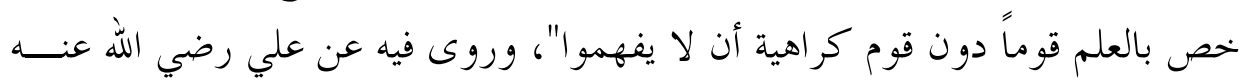

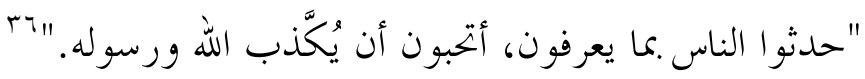

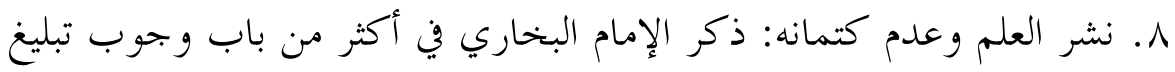

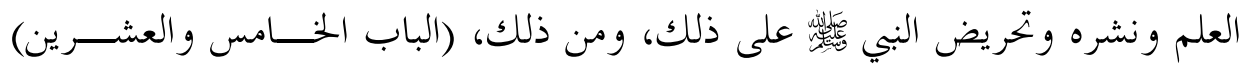

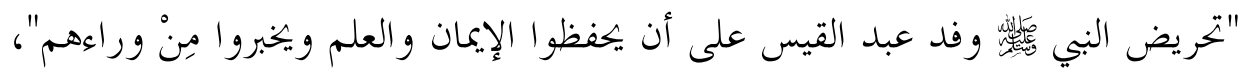

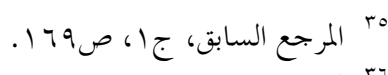

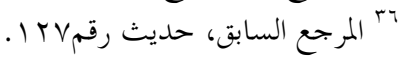




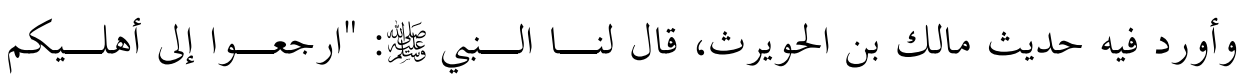

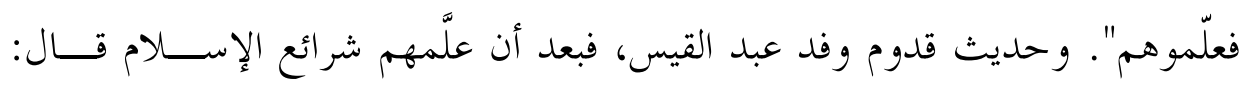

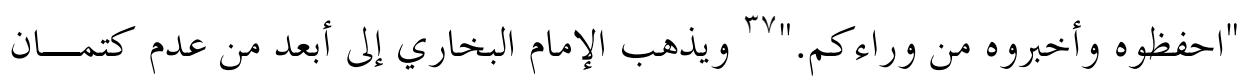

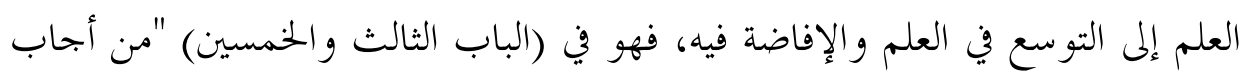

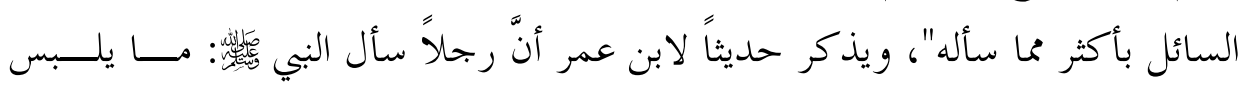

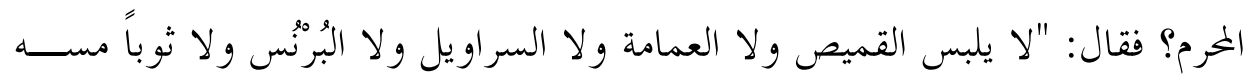

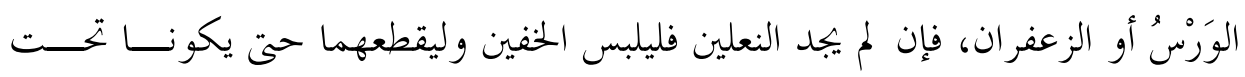

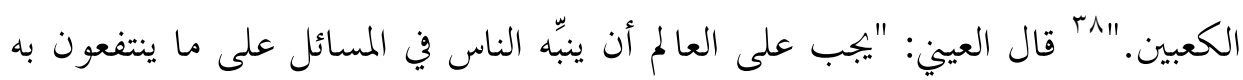

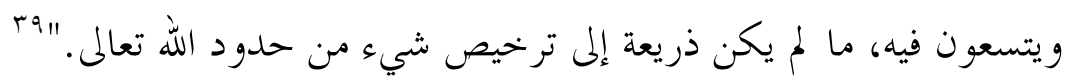

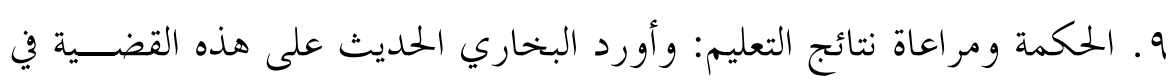

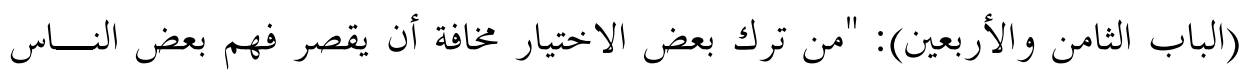

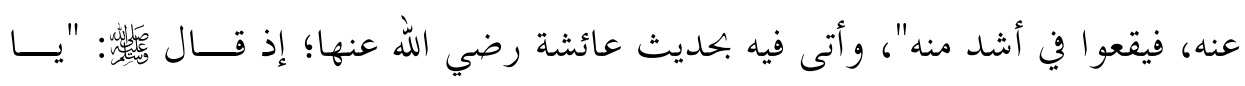

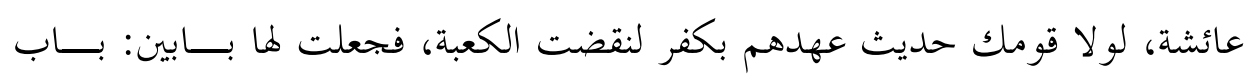

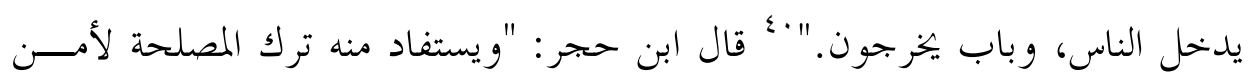

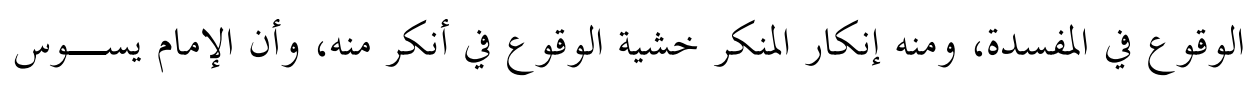

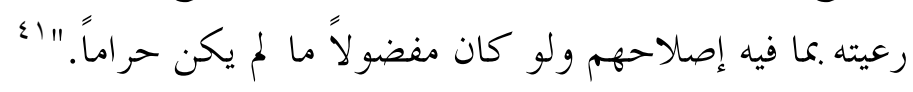

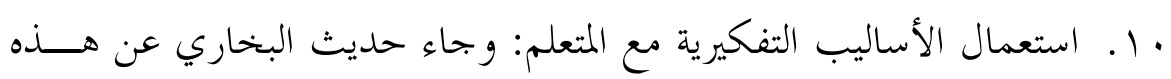

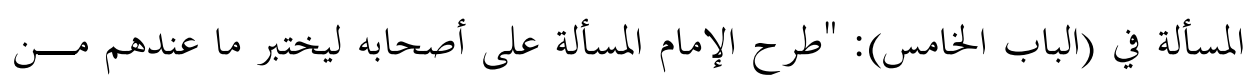

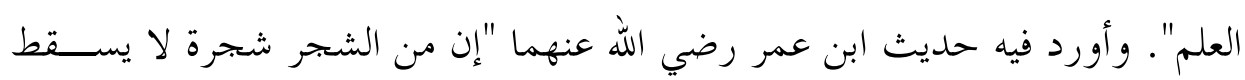

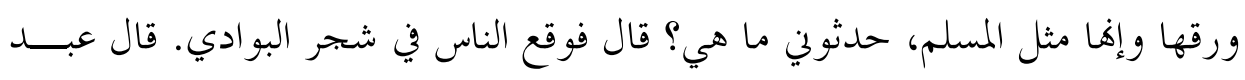

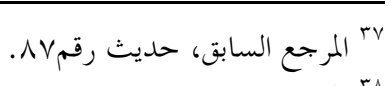

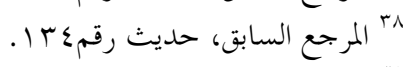

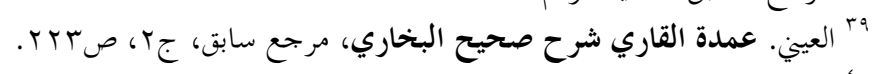

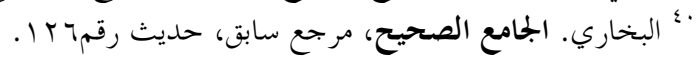

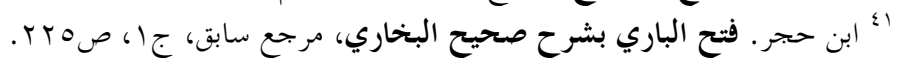




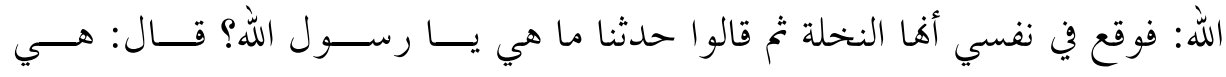

النخلة. "r"

رابعاً: أصناف المتعلمين ومواصفاقم

1. أصناف المتعلمين:

المتتبع للعناوين والأحاديث التي ساقها الإمام البخاري في كتاب "العلم"، يرى أنه

قسّم المتعلمين إلى عدة فئات بحسب حيثيات متعددة أهمها:

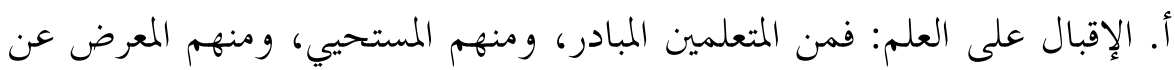

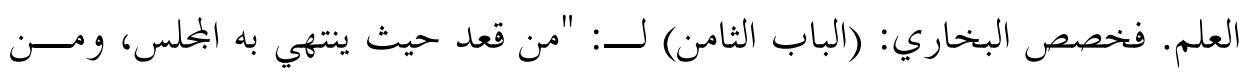
رأى فرجة في الحلقة فجلس فيها" وأورد فيه حديث أبي واقد الليثي رضي الله عنسـه:

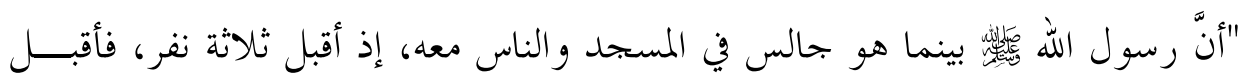

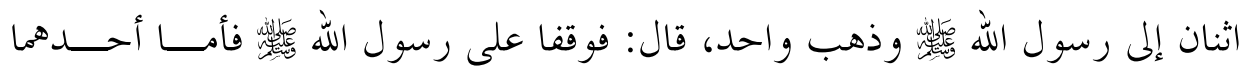

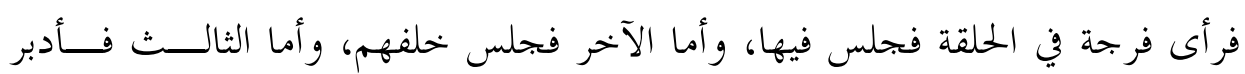

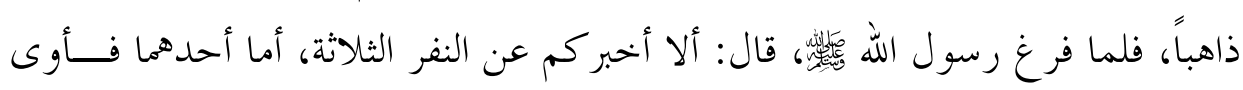

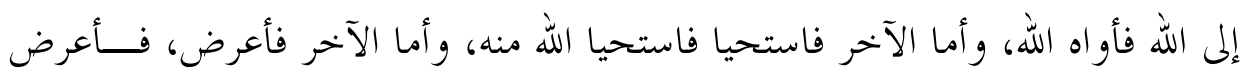

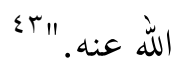

ب. الفهم: بيّن البخاري أنَّ الناس يتفاوتون في الفهم والإدراك و الوعي، فأورد في

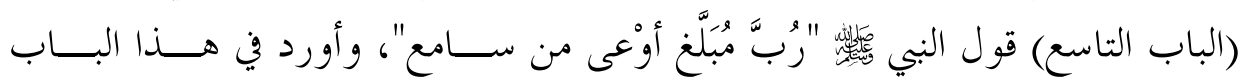

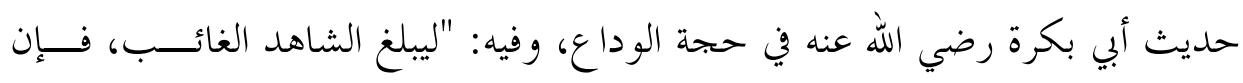

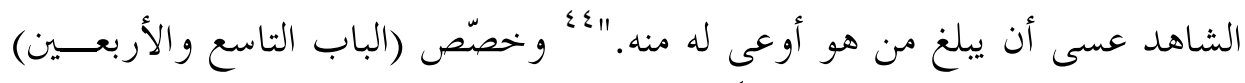

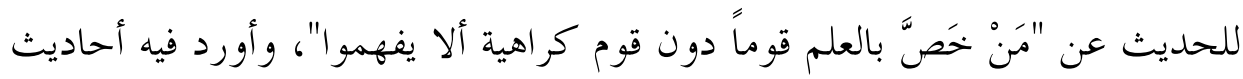

$$
\begin{aligned}
& \text { rأ البخاري. الجامع الصحيح، مرجع سابق، حديث رقمبا؟. }
\end{aligned}
$$

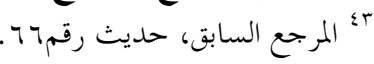

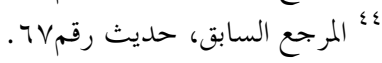




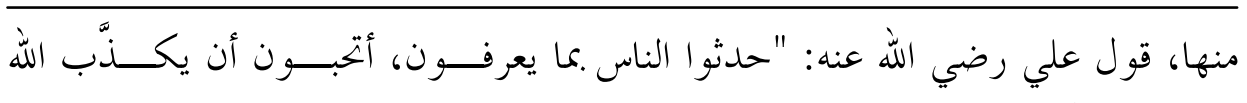

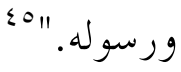

ت. تبليغ العلم والعمل به: وتناول البخاري هذه المسألة في (الباب العشــرين):

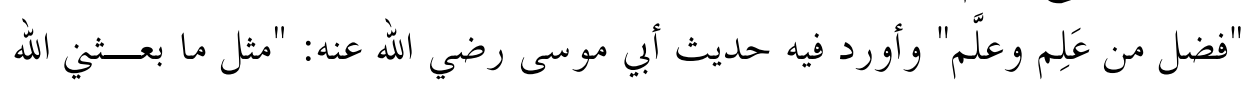

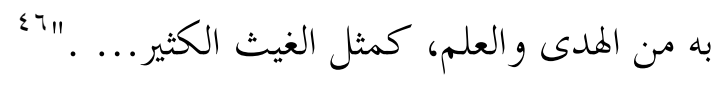

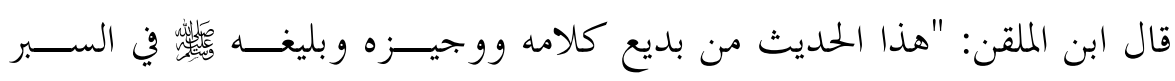

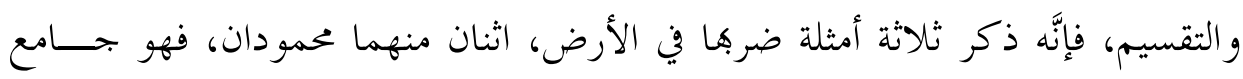

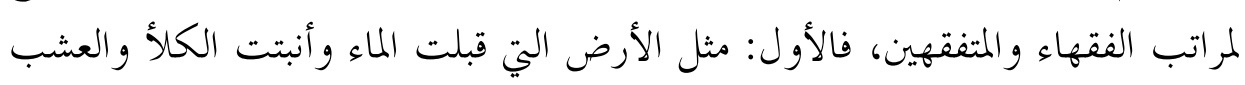

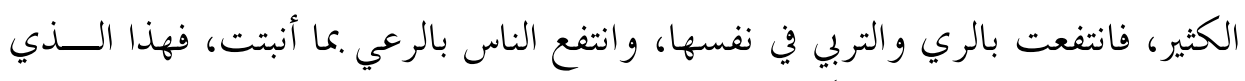

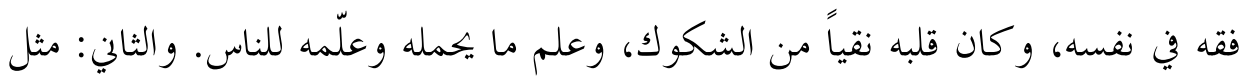

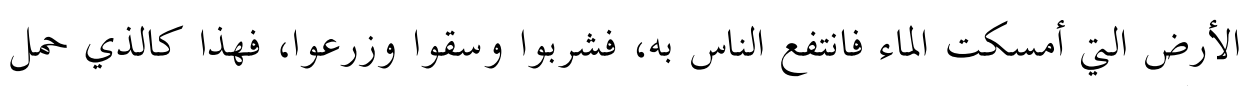

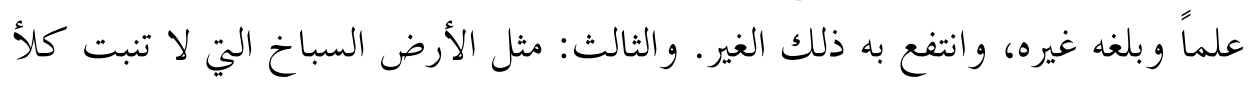

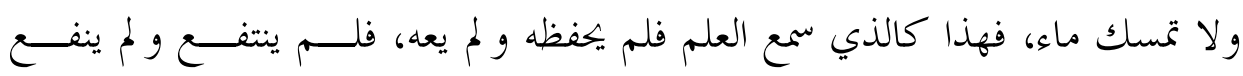

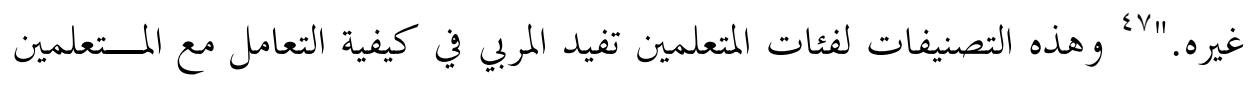

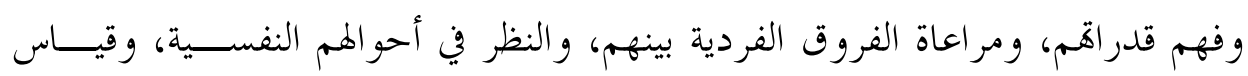
مخرجات التعليم عليهم.

\section{r ب . مو اصفات طالب العلم:}

كما اهتم الإمام البخاري .مواصفات المربي فإنَّه أشار إلى مواصفات المتعلم و آدابه، على النحو الآتي: - n أ. قوة الدافعية للتعليم: وعبّر عنها الإمام البخاري بكلمة "الحــــرص" في (البـــاب

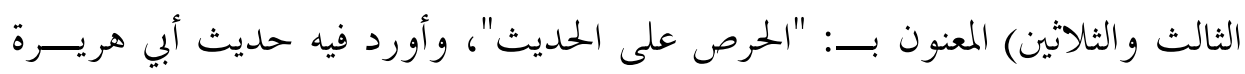

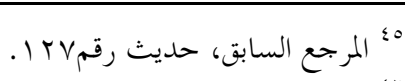

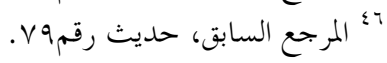

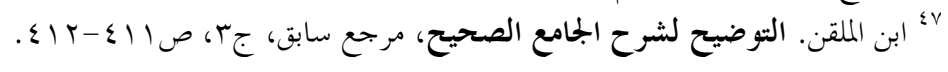




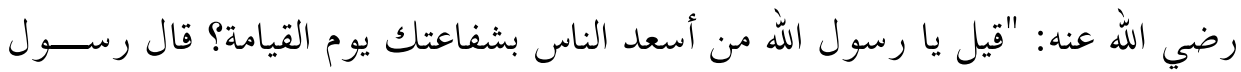

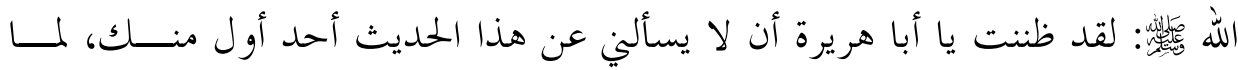
رأيت من حرصك على الحديث. أسعد الناس بشفاعتي يوم القيامة من قال: لا إله إلا لإئي

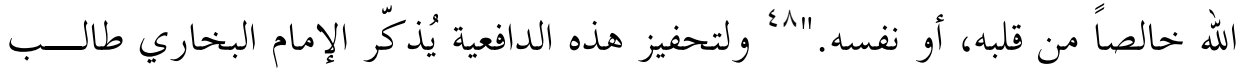

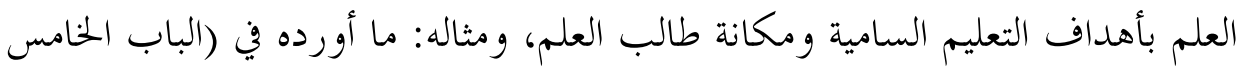
عشر): "الاغتباط في العلم والحلممة" وأورد فيه حديث ابن مسعود -رضي الله وله عنه-

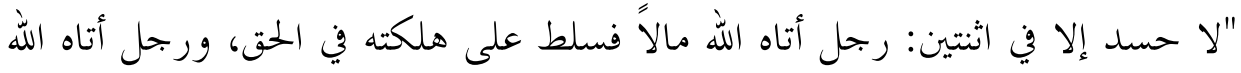

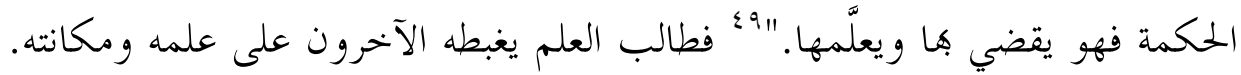

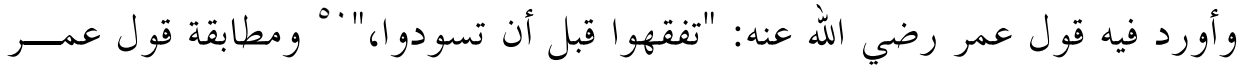

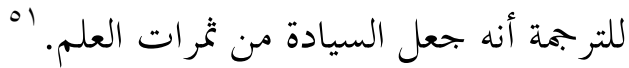
ب. البحث العلمي: أشار البخاري إلى موضوع البحث العلمي مما كان سائداً في

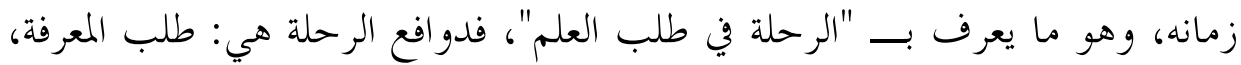

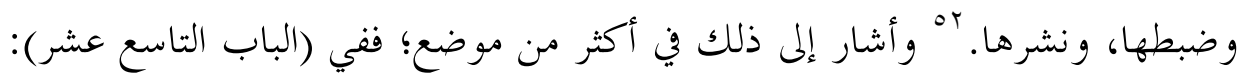

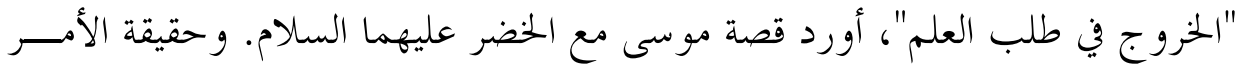

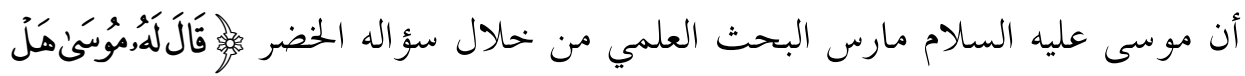

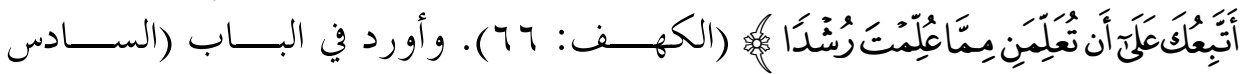

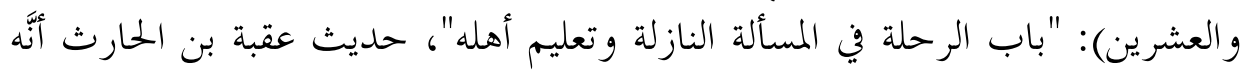

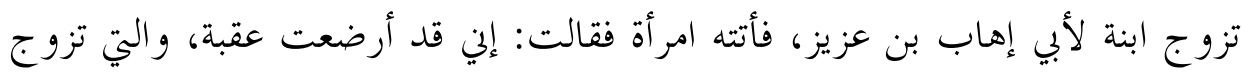

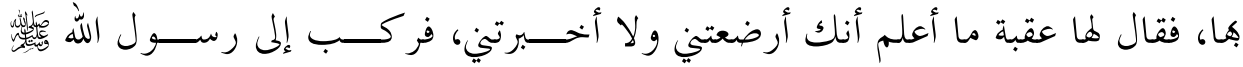

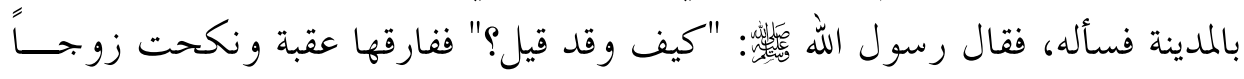
غيره. "ro" وقد كان عقبة رضي الله عنه .بمكة.

$$
\begin{aligned}
& \text { هُ المرجع السابق، حديث رقمو9 } 9 .
\end{aligned}
$$

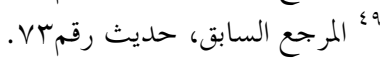

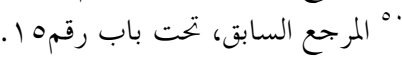

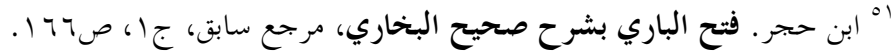

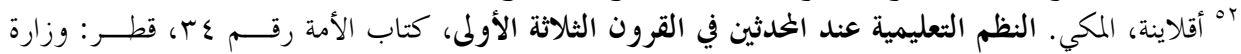

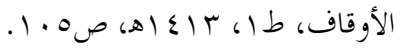

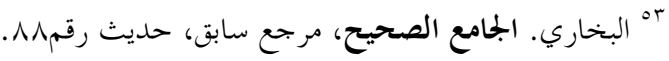


ت. الأمانة العلمية: خصّّ البخاري (الباب الثامن والثلاثين) بالحديث عن إثم من

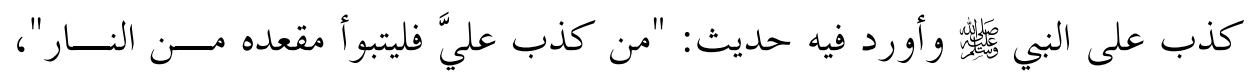

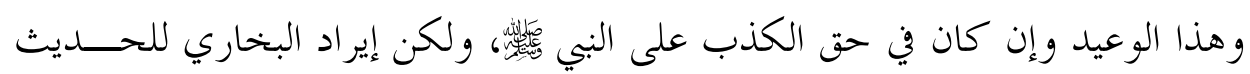
في كتاب العلم يشير إلى خطورة الكذب و التزوير في العلم.

ث. احترام العالم وتوقيره: وهو ما ناقشه البخاري في (الباب التاسع والعشرين):

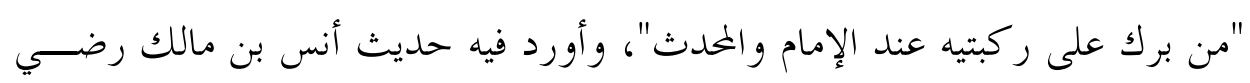

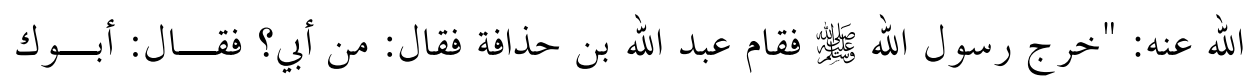

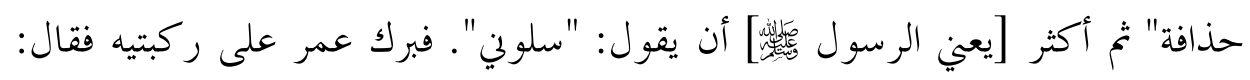

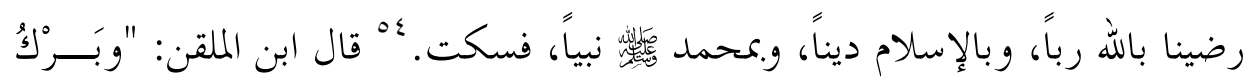

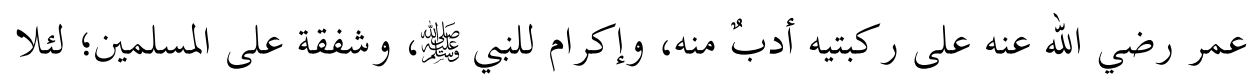

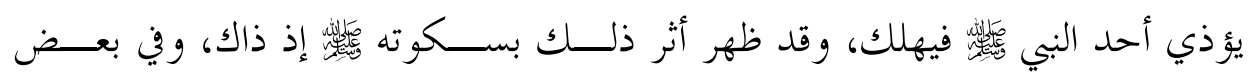

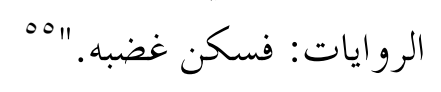

ج. التزام آداب بحلس العلم: ونوّه البخاري بأهميّة هذه المسألة في (الباب الثامن):

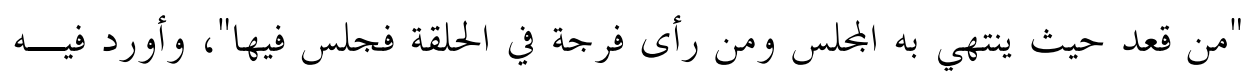

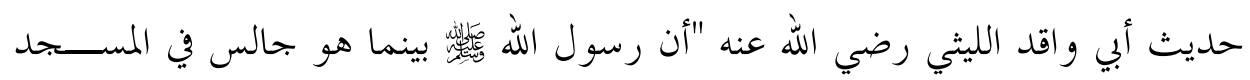

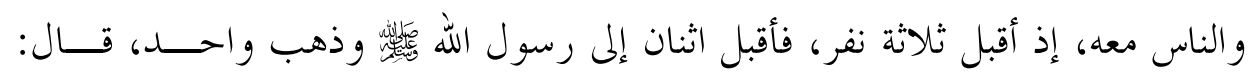

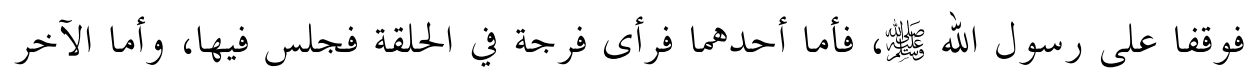

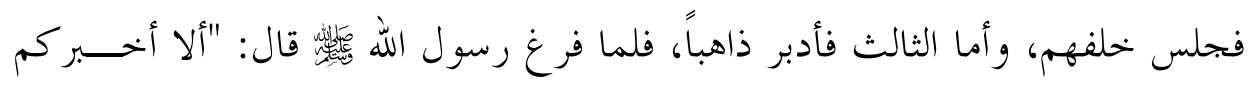

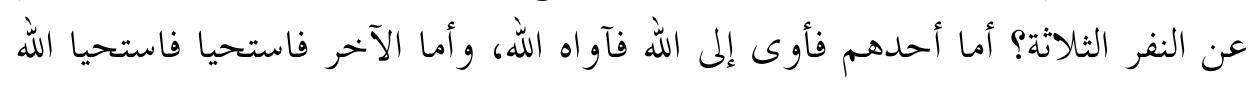

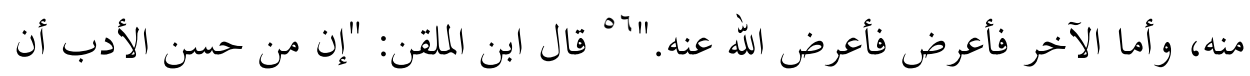

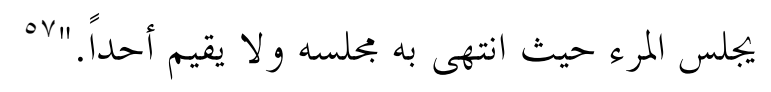

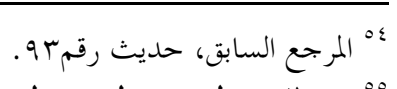

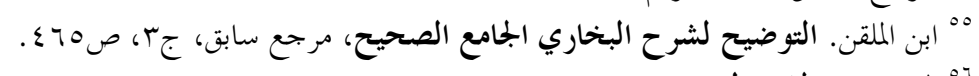

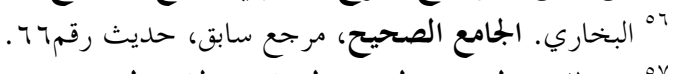

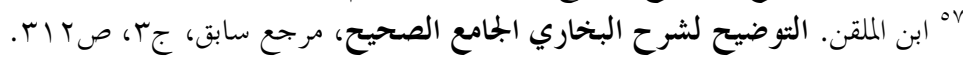


ح. الإنصات والانتباه في العلم: وقد نظر البخاري هذه المسألة في (الباب الثالث

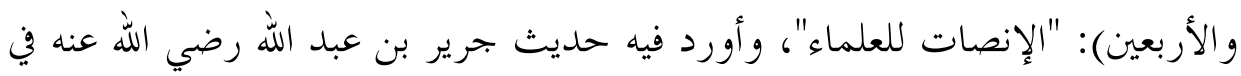
حجة الوداع، قول البي لئس

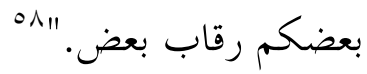

خ. المناقشة والحوار ومراجعة العالم إذا أُشكل عليه شيء في العلم: وهو ما خصّ المّل

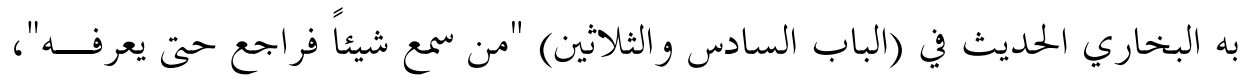

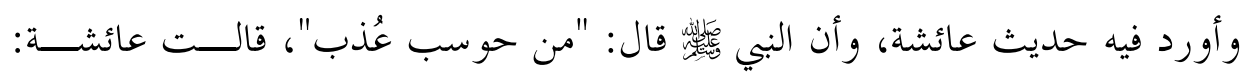

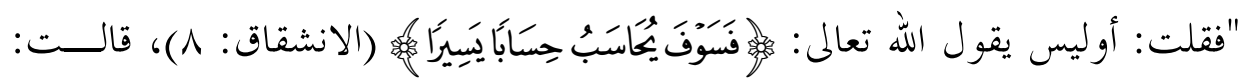

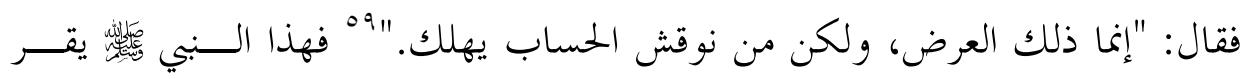

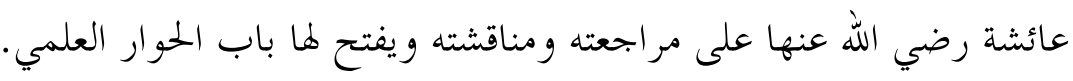
د. التواضع: وهو ما تحدث عنه البخاري في(الباب الخمسين): "باب الحيــاء في

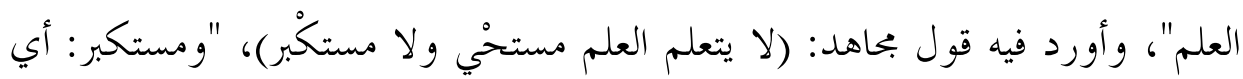

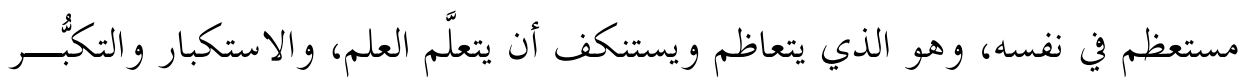

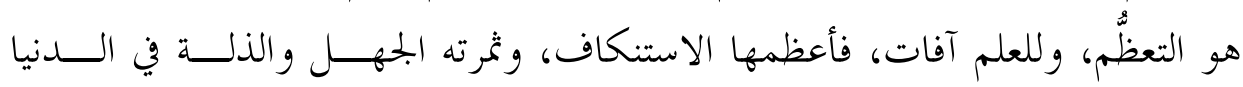

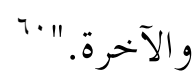

ذ. ترك الخجل في طلب العلم: فمن خلال التبويب السابق، بيَّن البخاري خطورة

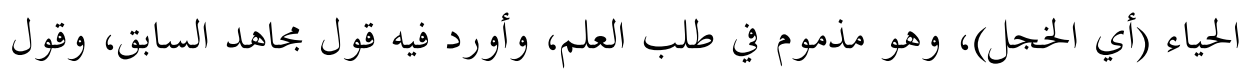

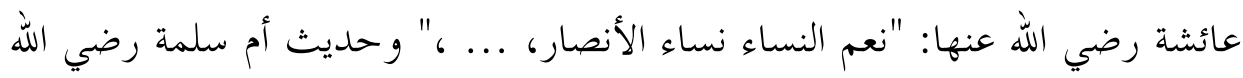

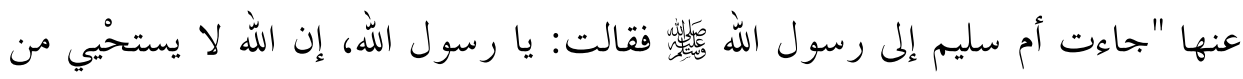

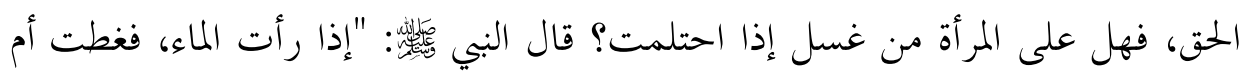

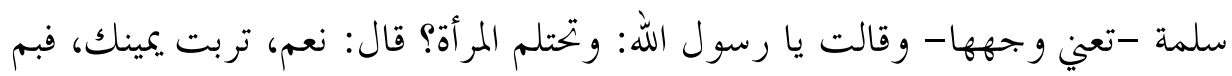

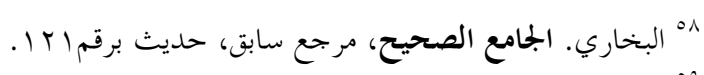

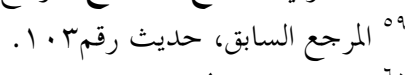

"' اليين. عمدة القاري شرح صحيح البخاري، مرجع سابق، جr، ص. آب. 


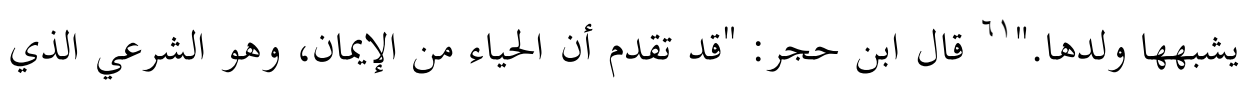

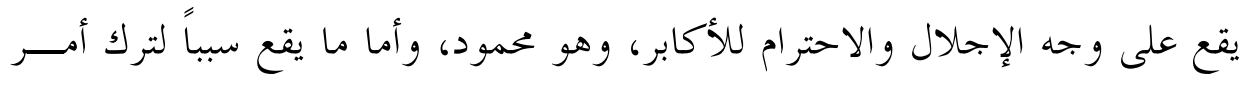

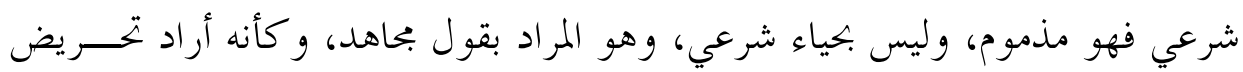

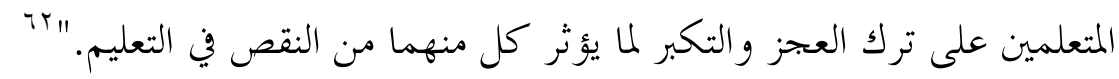
ر. الجمع بين الحفظ والفهم: أشار البخاري في باب "حفظ العلم"، وباب "الفهم في العلم"، إلى أن العلم يتطلب الحفظ كما يتطلب الفهم.

\section{خامساً: طرق التعليم عند الإمام البخاري و أدواته وأساليبه}

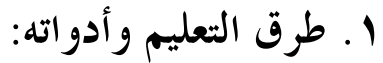

أورد الإمام البخاري في كتاب "العلم" أربع طرق تعليمية لرواية الحديث وهــي:

السماع، و القراءة و العرض، والمناولة، والمكاتبة. و تفصيلها على النحو الآتي:

أ. طريقة "السماع" فقد أوردها عَرَضضاً لأهنا الطريقة الأشهر، و الأكثـــــــــــــاولاً.

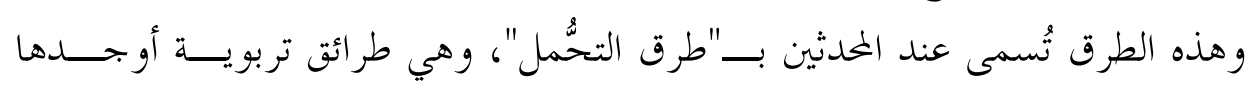
المحدثون في رواية الحديث لنقل الحلديث من الشيخ إلى التلميذ.

قال القاضي: "واعلم أن طريق النقل، ووجوه الأخذ، وأصول الرواية على أنواع

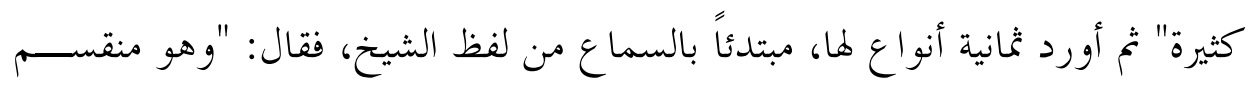

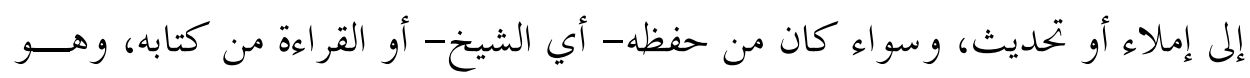

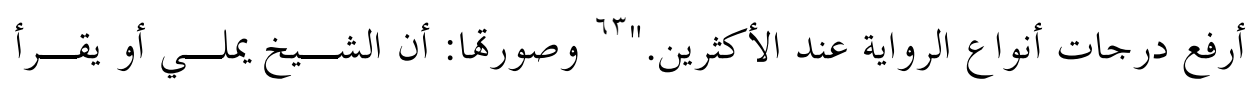
أحاديثه ومرو ياته على التلاميذ سواء من حفظه أو من كتابه.

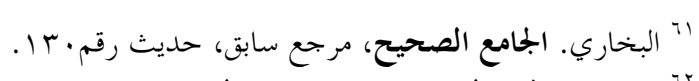

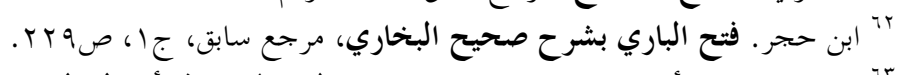

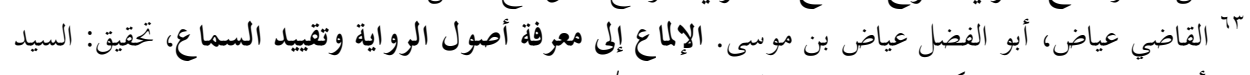

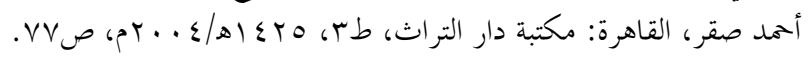




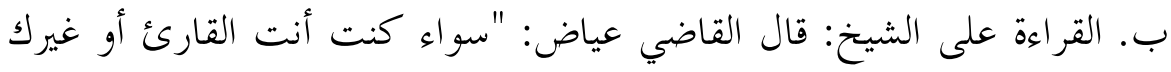

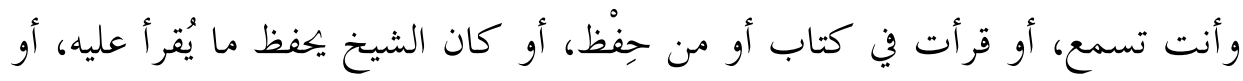

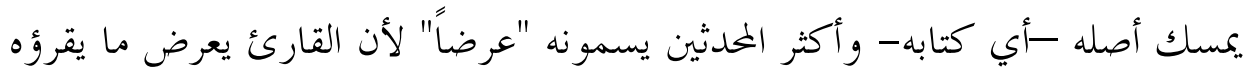

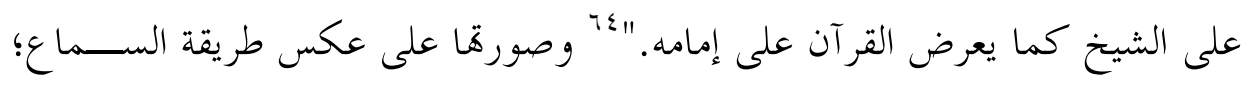

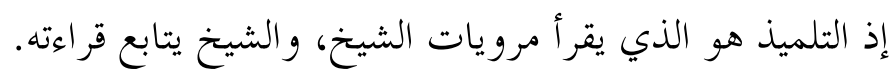

وفي (الباب السادس) ذكر البخاري ما جاء في العلم، أي؛ في طرقــه: القـــــاءة

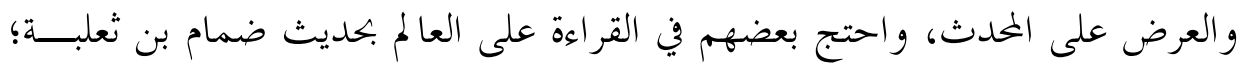

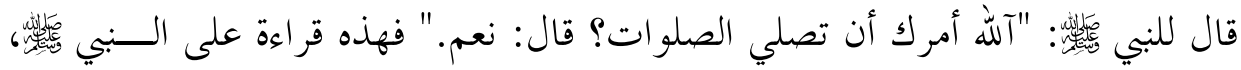

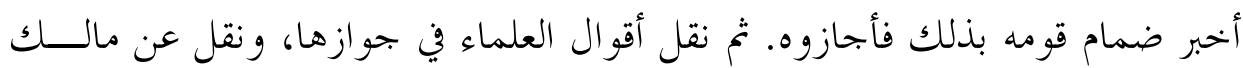

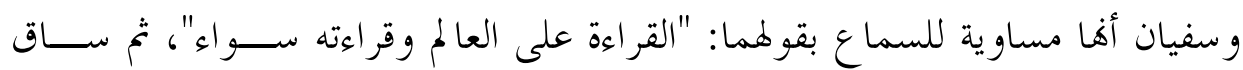
بإسناده المتصل حديث ضمام بن ثعلبة رضي الله عنه.

ت. المناولة: قال القاضي عياض وهي على أنواع: "أرفعها أن يدفع الشيخ كتابه

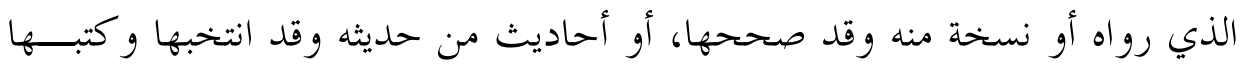

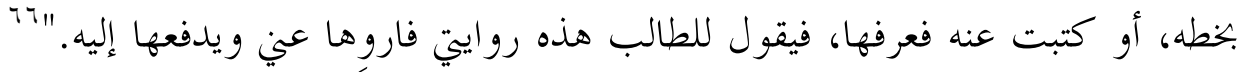

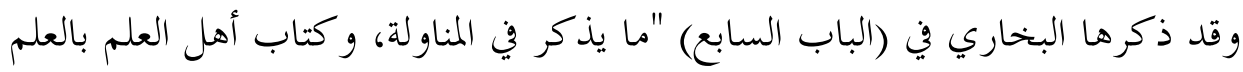

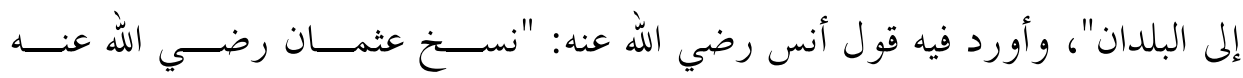

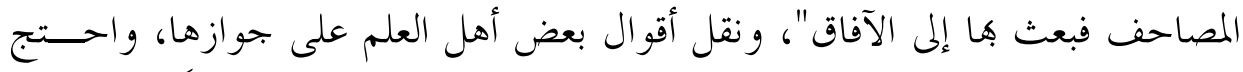

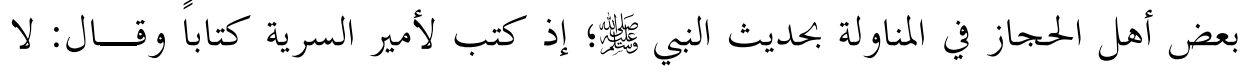

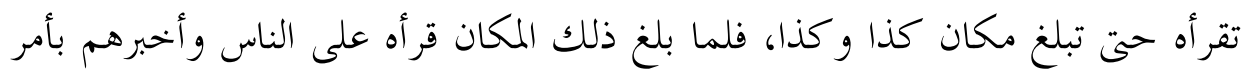
البي ث. المكاتبة: "وهي أن يسأل الطالب الشيخ أن يكتب له شيئاً من حديثه، أو يبدأ

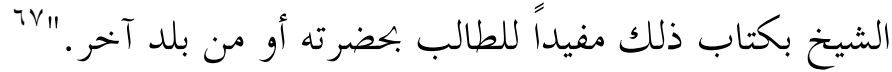

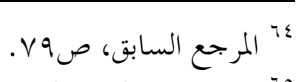

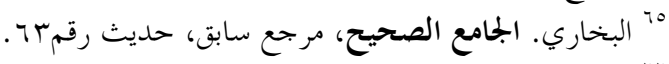

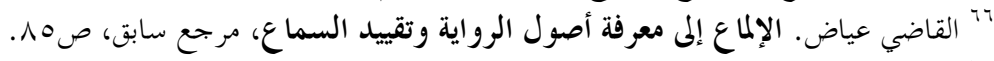

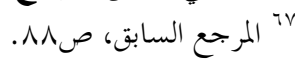




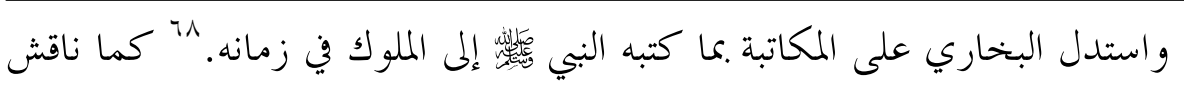

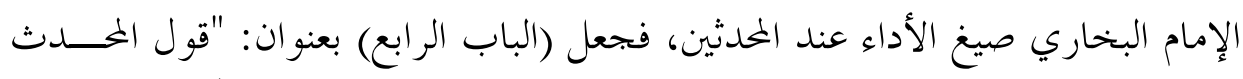

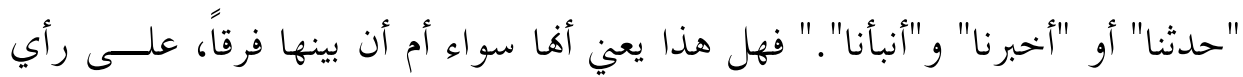

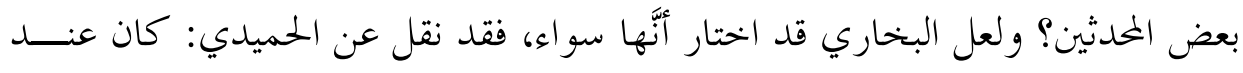

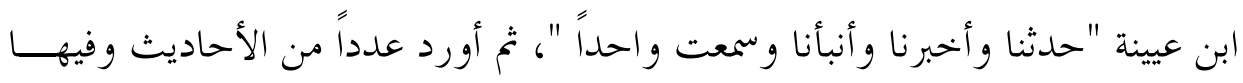
استعمال هذه الصيغ.

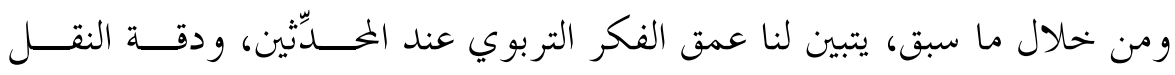
و الضبط عندهم من خلال طرق التحمُّل التي وضعوها، ودقيق ملحظ الإمام البخاري؛ إذ أثبت مشروعية هذه الطرق من السنة النبوية.

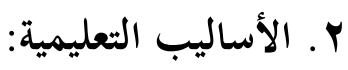

قبل الخوض في الأساليب التعليمية التي اعتىن هـا الإمام البخاري في كتاب العلـــم،

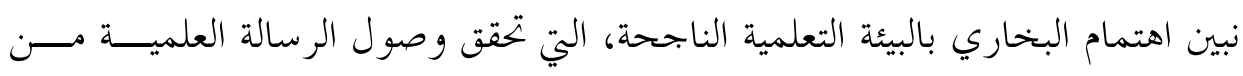

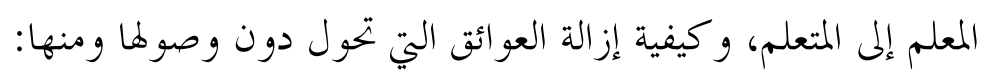
أ. رفع الصوت بالرسالة العلمية عند الحاجة إلى ذلك لتأكد وصوها إلى المــتعلم: وقد أوضحها البخاري في (الباب الثالث) "من رفع صوته بالعلم"، و ساق فيه حديث

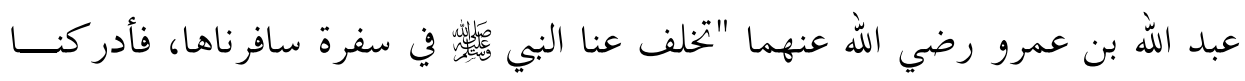
وقد أرهقتنا الصلاة ونحن نتوضأ، فجعلنا نمسح على أرجلنا، فنادى بأعلى صوته "ويل

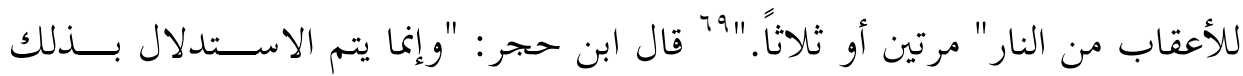

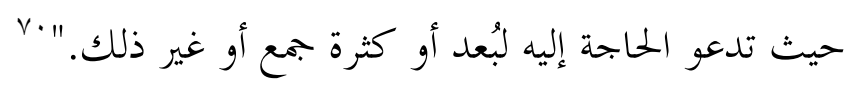

ب. عدم إيقاع الملل على المتعلم: وتحدّث عنه البخاري في (الباب الحادي عشر):

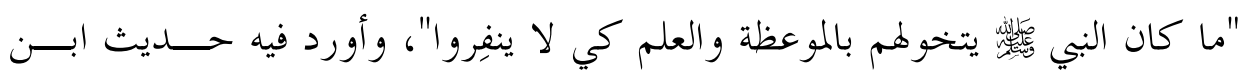

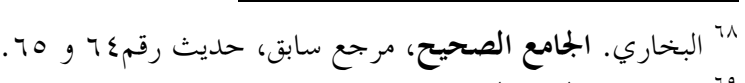

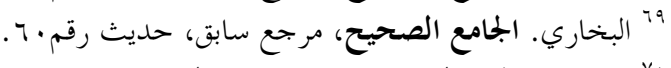

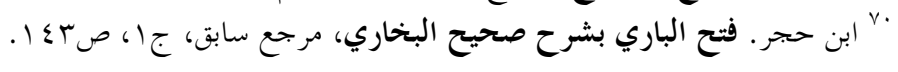




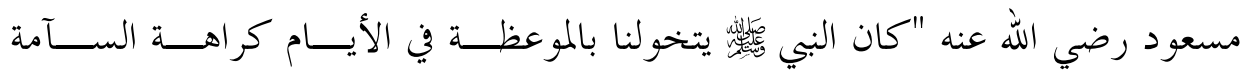

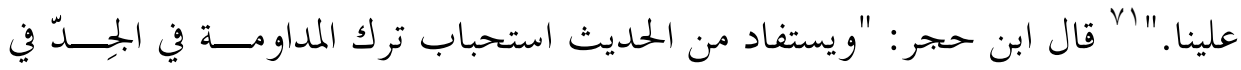

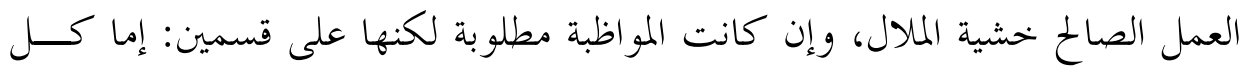

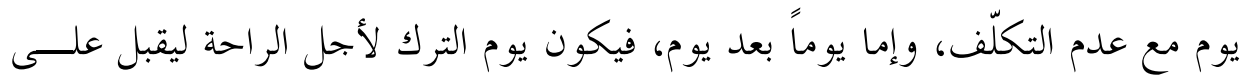

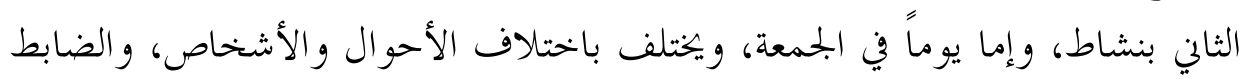

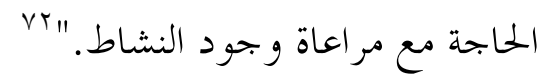

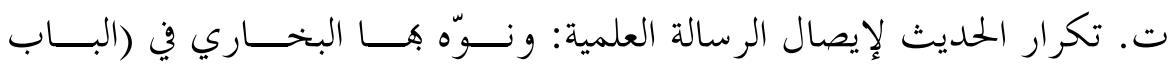

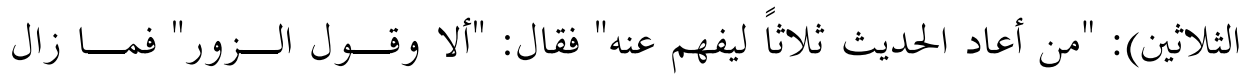

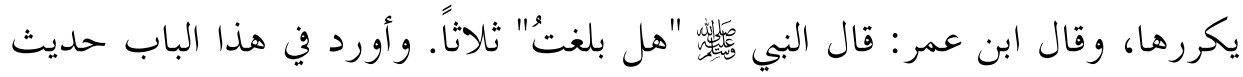

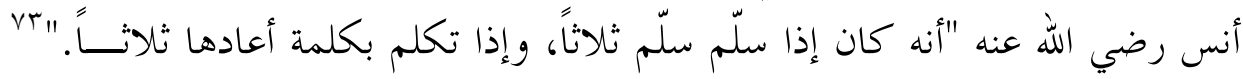

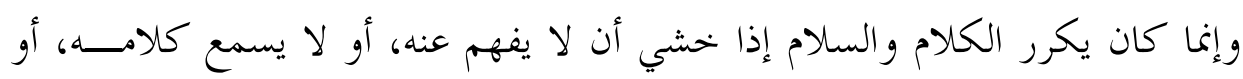

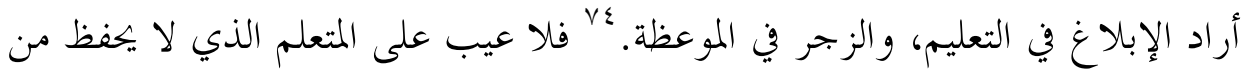

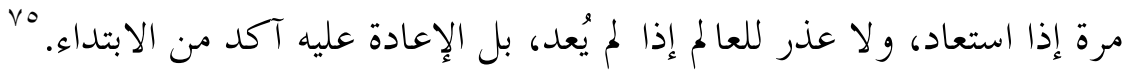
ث. الجو العلمي الهادئ لتحقيق الإنصات للمعلم: تحدّث البخاري في هذه المسألة

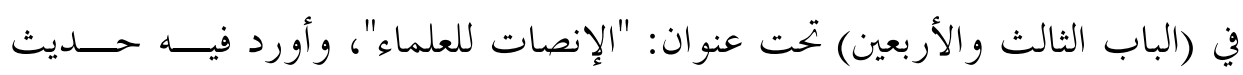

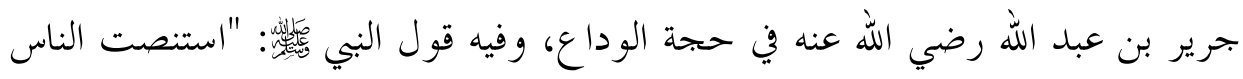

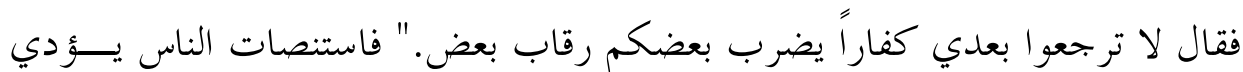
إلى حسن وصول الرسالة التعليمية للمتعلم.

ثمة أساليب تعليمية عديدة ذكرها البخاري في كتاب العلم، من أهمها:

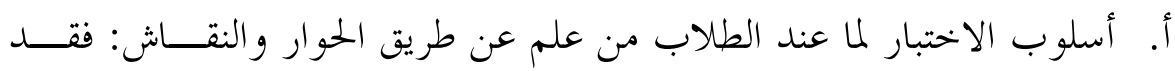

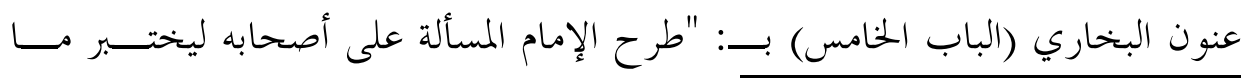

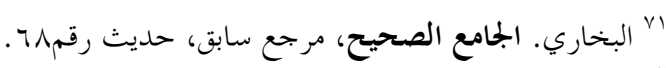

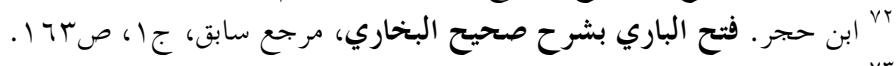

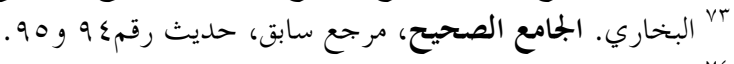

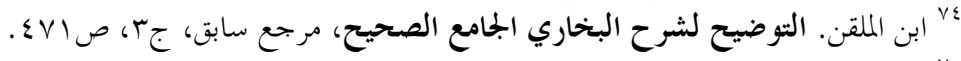

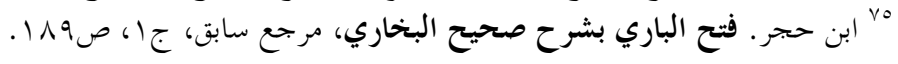




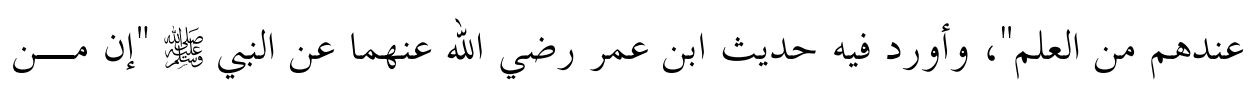
الشجر شجرة لا يسقط ورقها ..." كما يخفي مع بيانه لهم إن لم يفهموه.

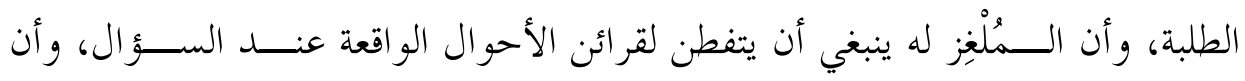

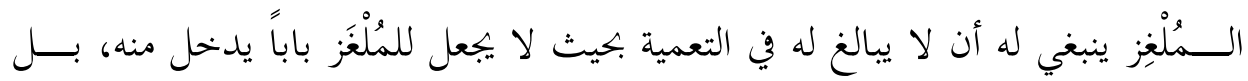

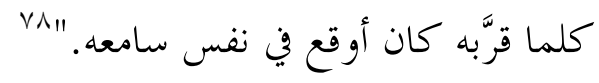

ب.أسلوب التدرج في التعليم: ذكر البخاري في (الباب العاشر) "العلم قبل القول و العمل" ويقال الرباني: (الذي يربي الناس بصغار العلم قبل كباره). وهذا يكون الإمام البخاري قد سبق كبار المفكرين التربويين في ذلك، ومنهم ابن خلدون الذي نــادى بالتدرج في التعليم. وهو لا يختلف في فكره التربوي عما تنادي به التربية الحديثة، من

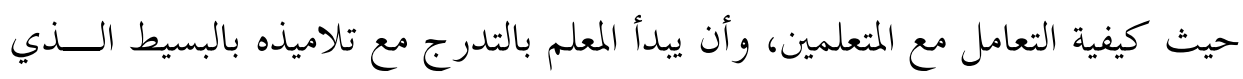

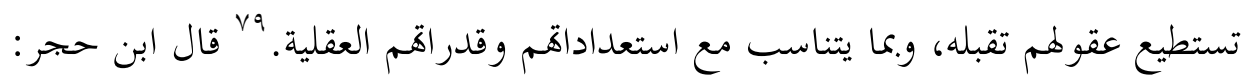

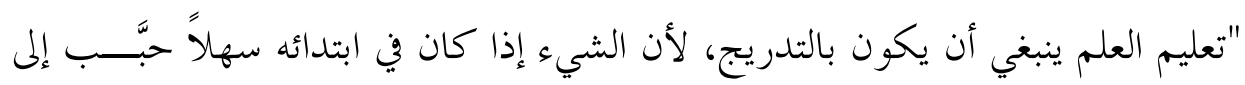

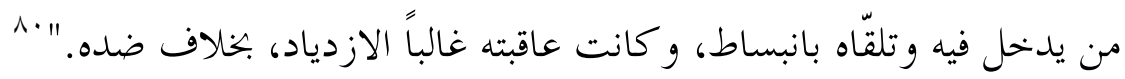

ت. استعمال لغة الجسد لإيصال الرسالة التعليمية: وقد أشار البخاري إلى هـــهـ المسألة في (الباب الرابع والعشرين): "من أجاب الفتيا بإشارة اليد والرأس"، وأورد فيه

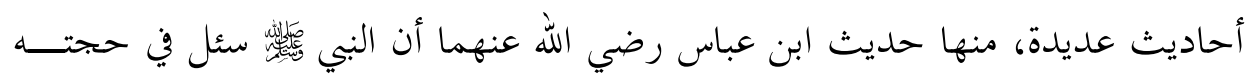

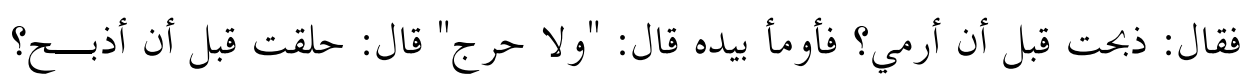

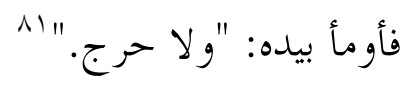

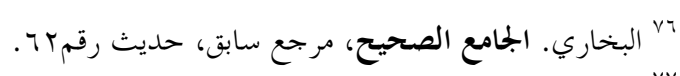

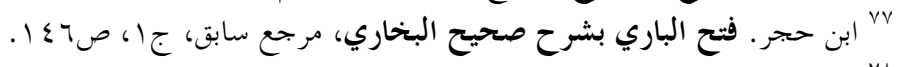

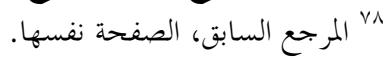

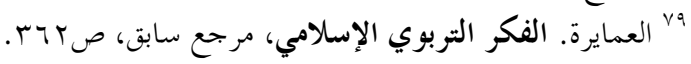

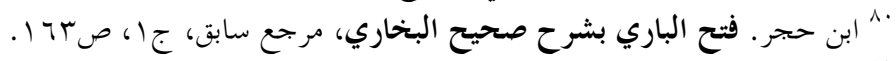

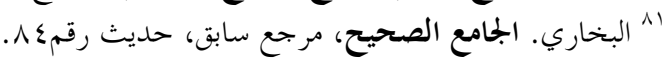


ث. أسلوب الغضب في التعليم عند الحاجة إليه: خصصّ البخاري (الباب الثامن

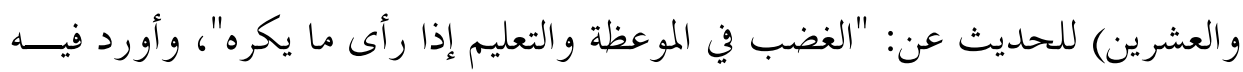

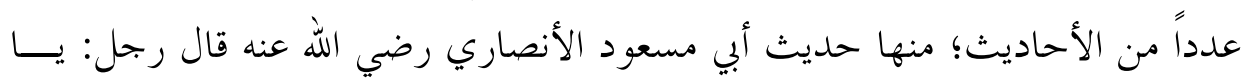

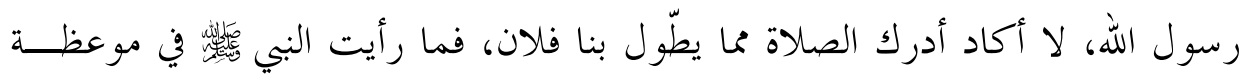

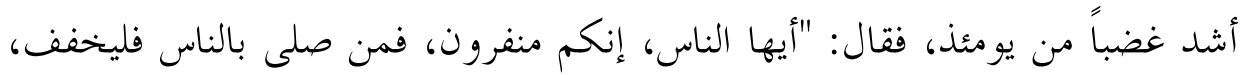

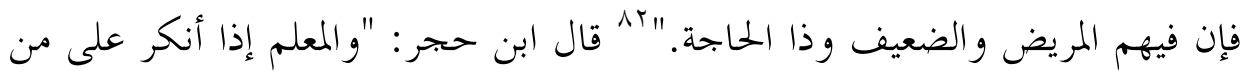

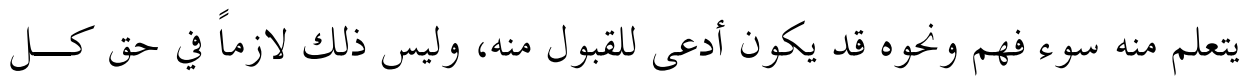

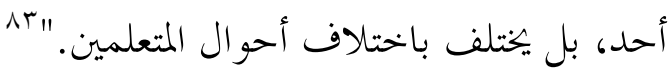

ج. فتح باب الحوار العلمي: جعل البخاري (الباب السادس والثلاثين) بعنــــوان:

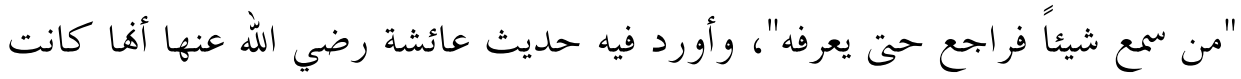

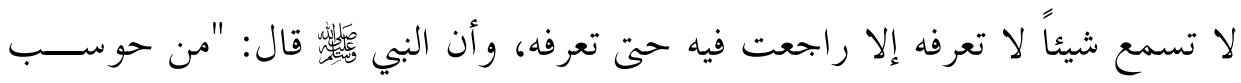

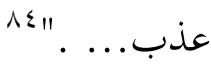

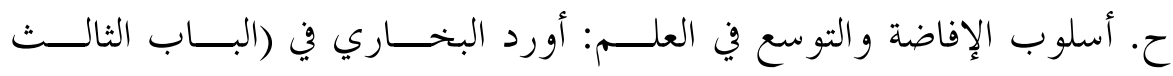

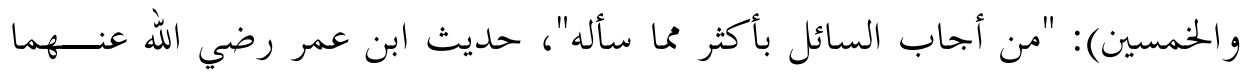

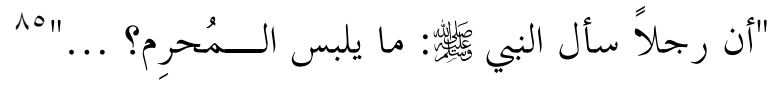

سادساً: البعد الزماني و المكاني للتعليم عند الإمام البخاري

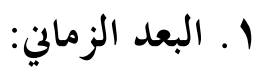
أورد الإمام البخاري في كتاب "العلم" أوقات التعليم مبيناً أثرها علــى المــتعلم

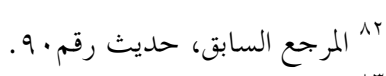

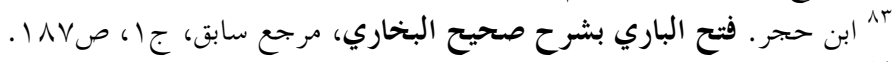

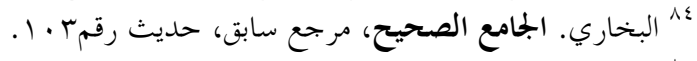

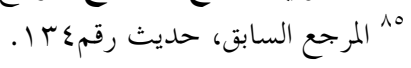




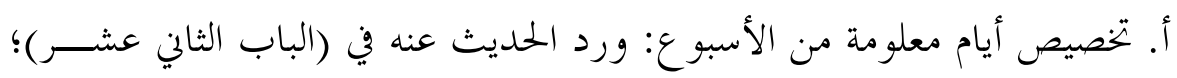

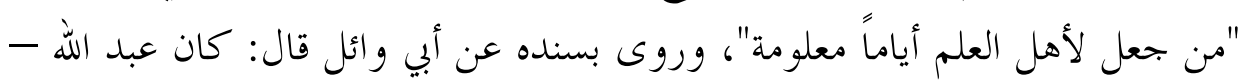

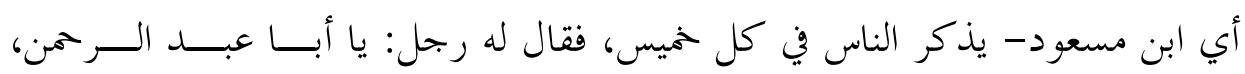

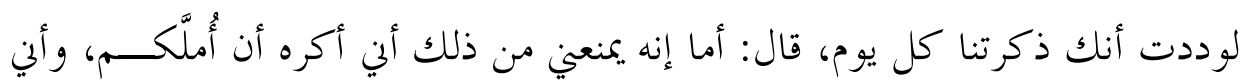

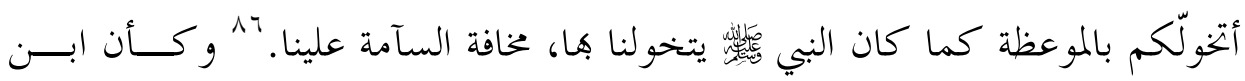

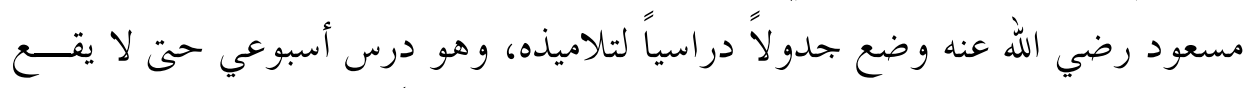

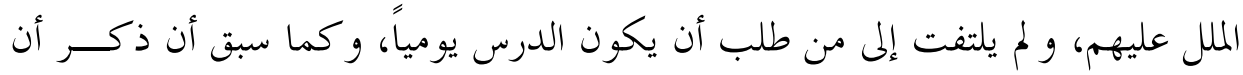

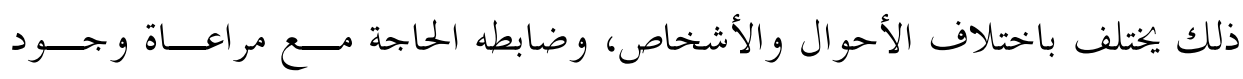
النشاط.

ب. تخصيص يوم لتعليم النساء: خصّص له البخاري (الباب الخامس والــثلاثين):

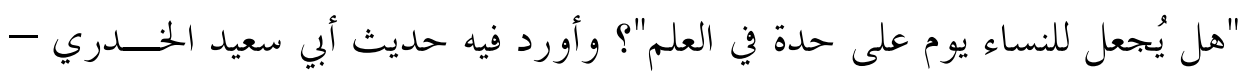

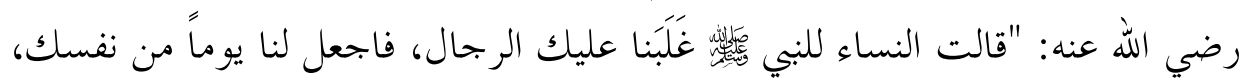

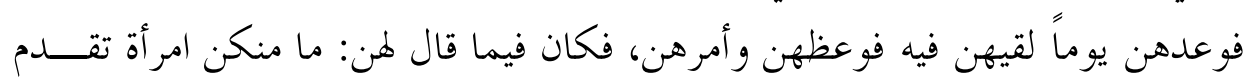

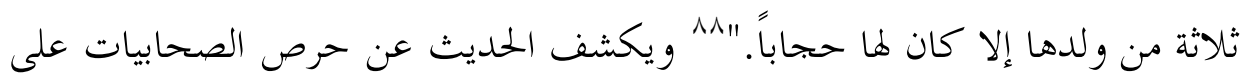

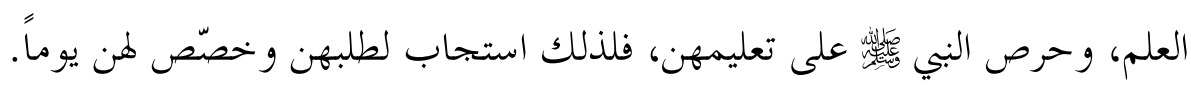

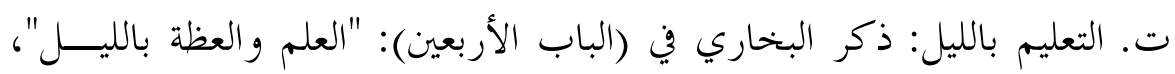

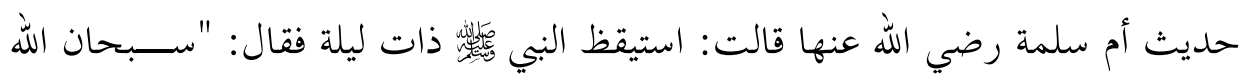

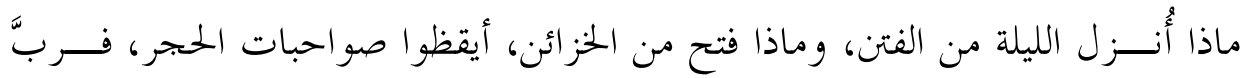

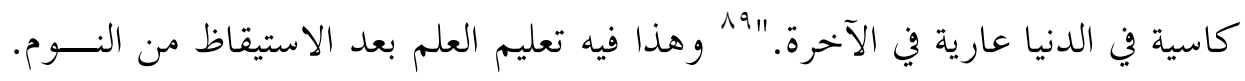

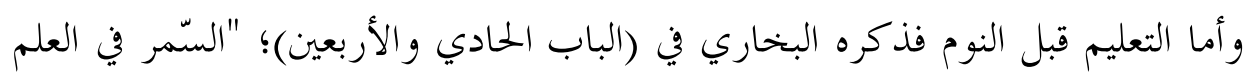

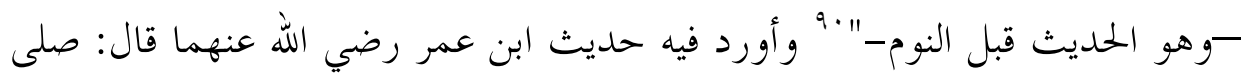

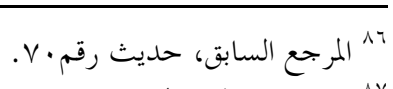

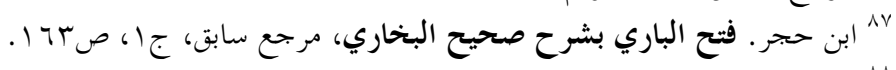

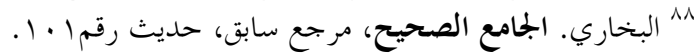

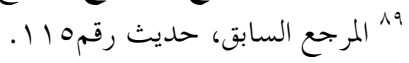

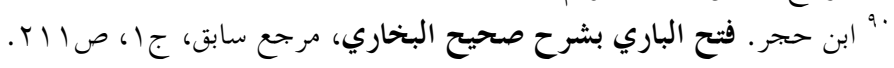




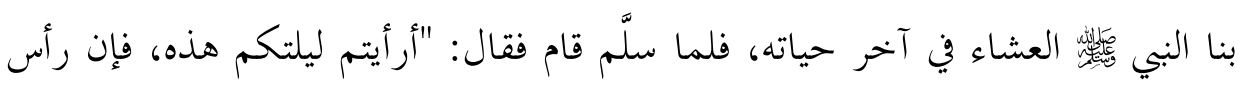

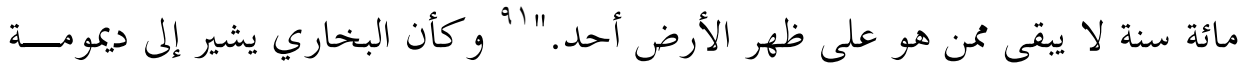

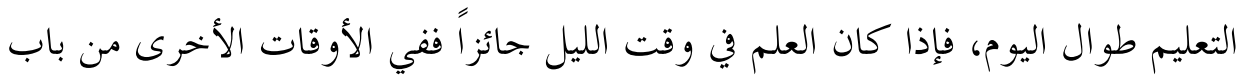

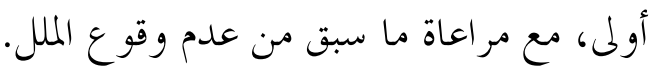

ث. أوقات خاصة ببعض الحالات: خصّص البخاري للحديث عن هذه المســـألة،

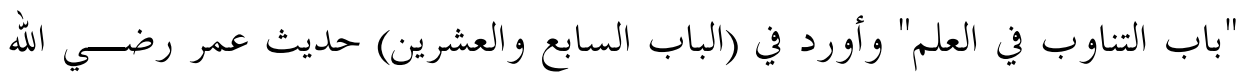

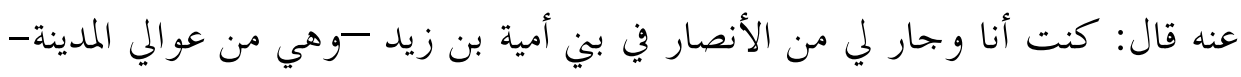

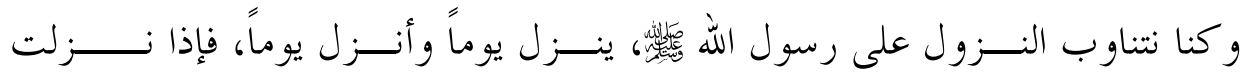

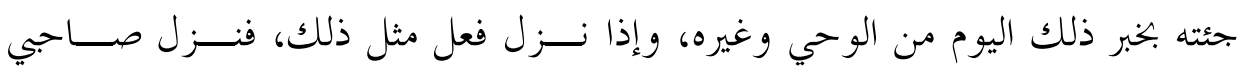

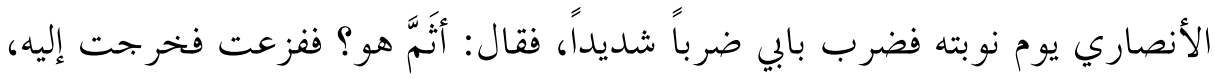

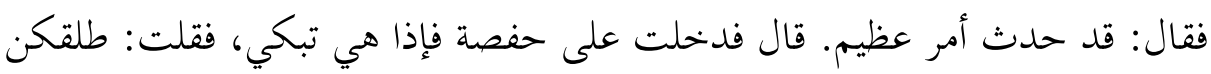

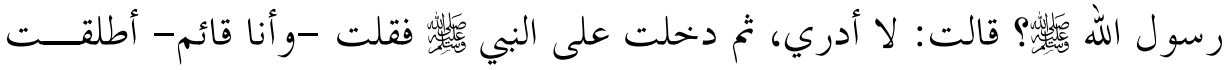

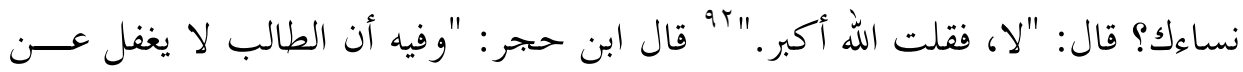

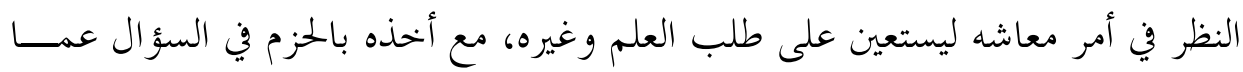

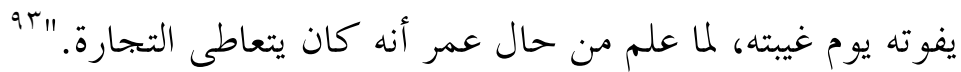

\section{ب. البعد المكالي (التعليم في المسجد):}

وذكر البخاري هذه المسألة في (الباب الثاني والخمسين) "باب: ذكر العلم والفتيا

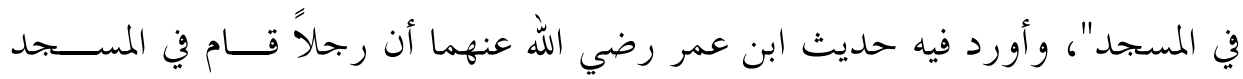

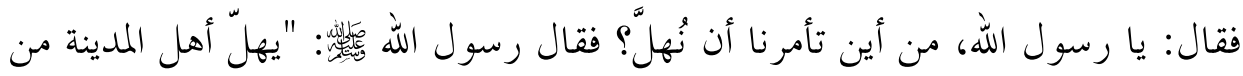

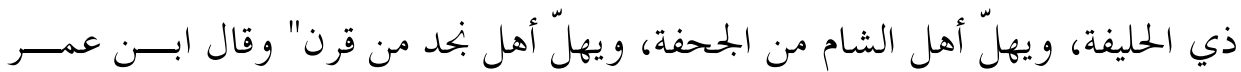

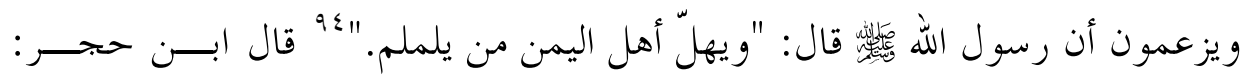

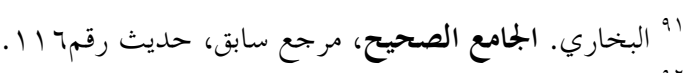

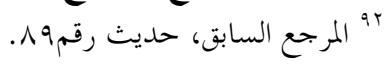

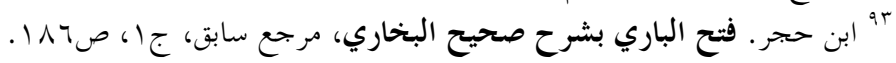

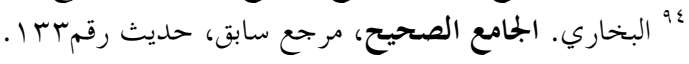




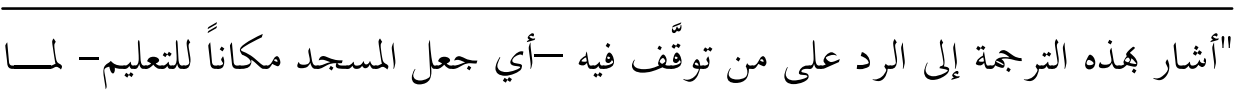

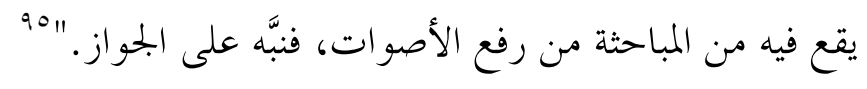

وعن كيفية التعليم في المسجد بيّن البخاري في (الباب الثامن) من مسألة "من قعد

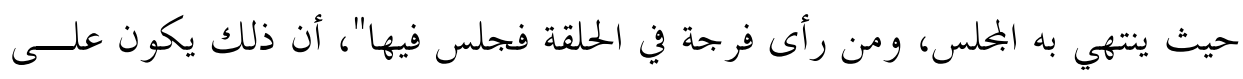
هيئة حلقة تعليمية.

\section{سابعاً: آراء الإمام البخاري في بعض القضايا التربويـــة، ومصــــلحاته ومفاهيمــهـ

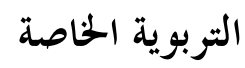

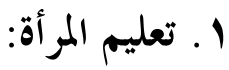

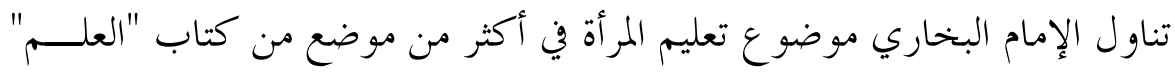
و وفي جوانب مختلفة، على النحو الآتي:

أ. ترتيب الأجر على تعليم المرأة: وهو ما ورد الحلديث عنه في البـــاب (الحــــادي

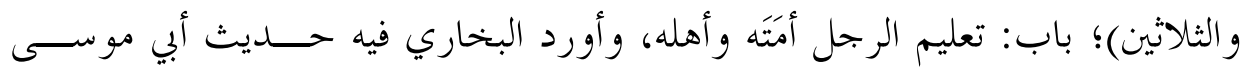

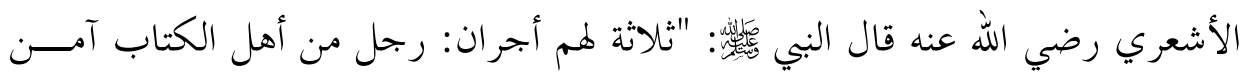

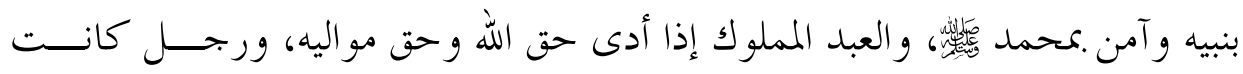

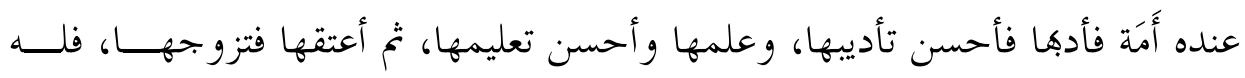

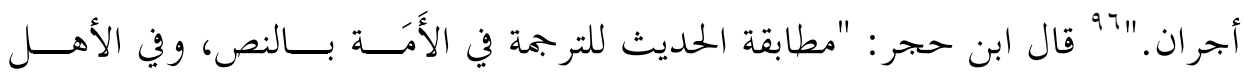
بالقياس؛ إذ الاعتناء بالأهل الحرائر في تعليم فرائض الله وسنن رسوله آكد من الاعته الإيناء

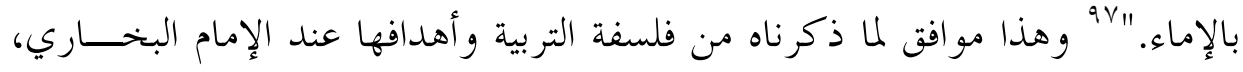
وأنه لتحقيق العبودية لله تعالى، فلذلك رتب الشارع الحلكيم الأجر على التعليم. ب. تعليم المرأة من المسؤوليات العامة: فبعد الباب الســـابق أورد البخـــاري في (الباب الثاني والثلاثين) "عظة النساء وتعليمهن"، وذكر فيه حديث ابن عباس رضــي

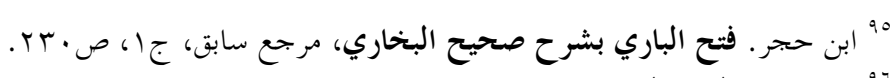

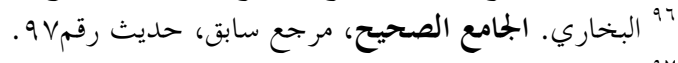

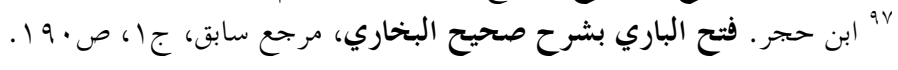




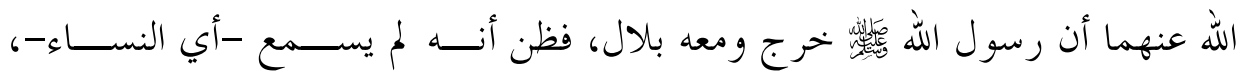

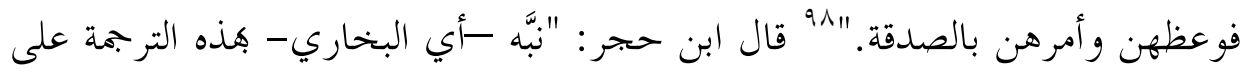

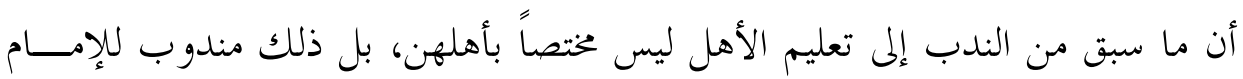

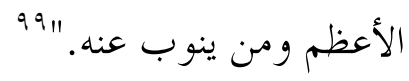

ت. تخصيص يوم لتعليم النساء: ذكر البخاري هذه المسألة في (الباب الســادس

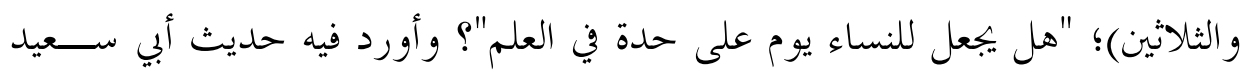

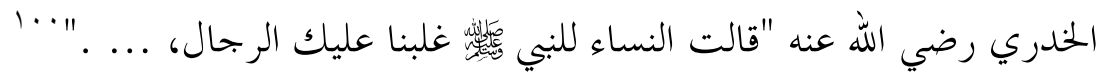

ث. حق المرأة في الحوار العلمي: وهو ما تحدّث عنه البخاري في (الباب السادس

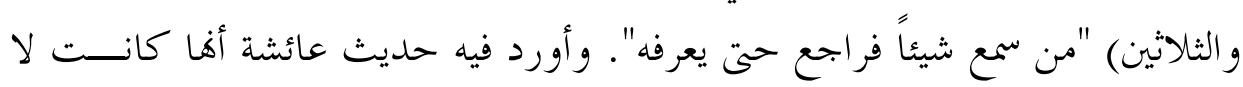

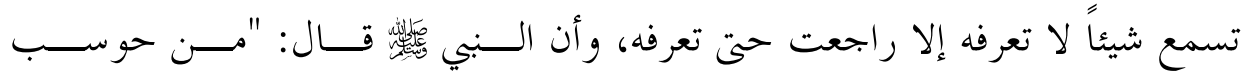

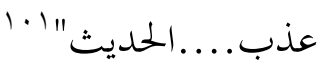

ج. الحياء لا يمنع المرأة من العلم: أورد البخاري في "باب: الحياء في العلم"، وهو

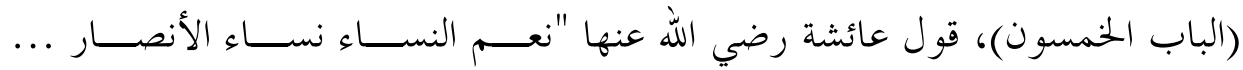

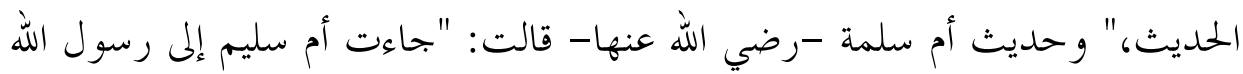

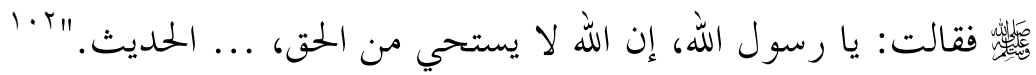

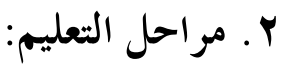

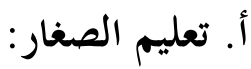

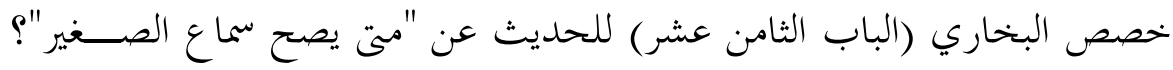

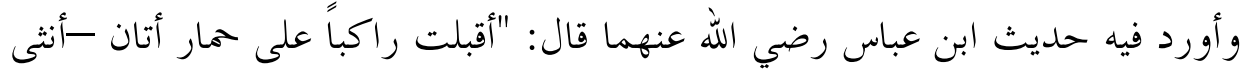

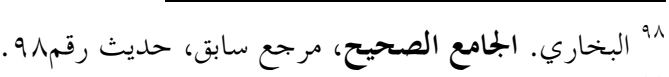

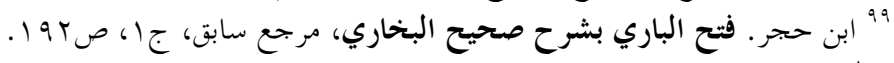

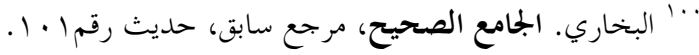

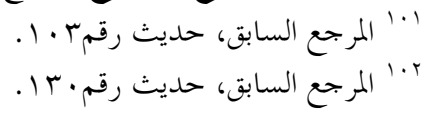




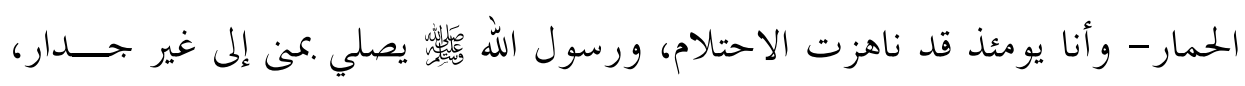

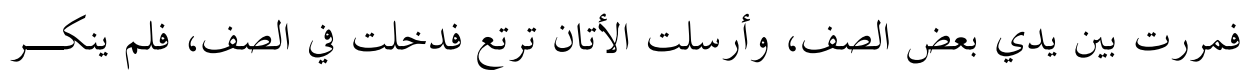

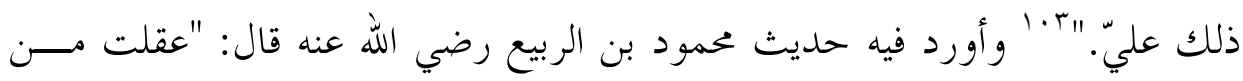

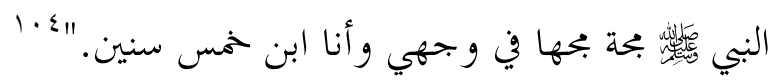
فالبخاري يرى أن الصغير متى كان فاهماً فهو أهل للتعليم، قال ابن حجر: "وليس

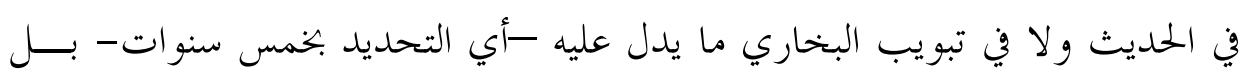
الذي ينبغي في ذلك اعتبار الفهم. والظاهر أهم أرادوا بتحديد الخمس أها مظنة ذلك،

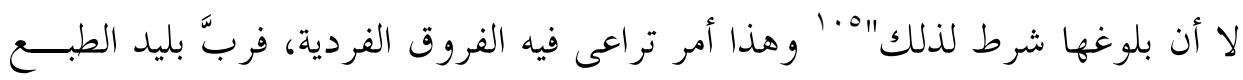

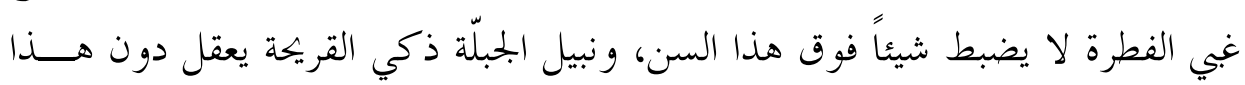
السن.

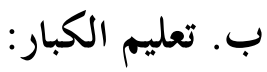

أشار البخاري إلى موضوع تعليم الكبار عرضاً في ثنايا (الباب الخامس عشــر)؛ "الاغتباط في العلم والحكمة"؛ إذ أورد قول عمر رضي الله عنه تفقهوا قبل أن تسودوا.

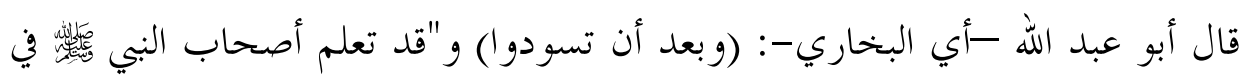

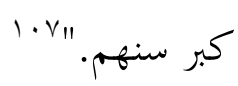

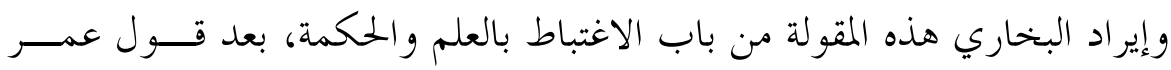
رضي الله عنه؛ إذ يدل على حثه للكبار بتحصيل العلم، وأن لا يكون كبر السن مانعاً لطلب العلم، فإنه سيحصل على الغبطة و السيادة المذكورتين، وهذا ما حصل للصحابة رضو ان الله عليهم.

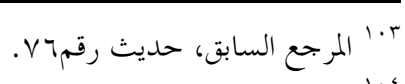

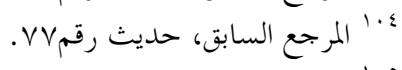

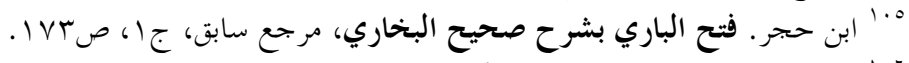

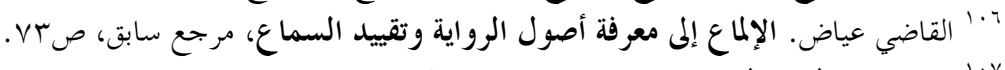

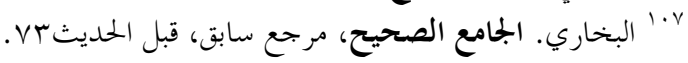




\section{r. كتابة الحلديث النبوي:}

بين البخاري رأيه في موضوع كتابة الحديث النبوي، وأن ذلك وقع في زمن النبي

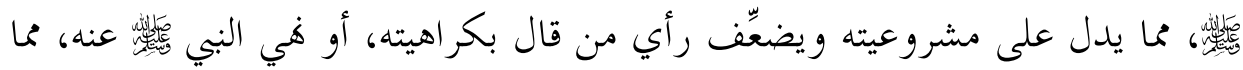
فتح البحال للطاعنين بالسنة النبوية محتجين بأن السنة النبوية لم يكتب شيء منها بـا إلا بعد

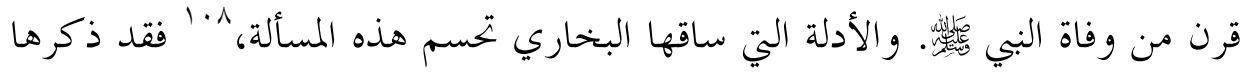
في (الباب التاسع و الثلاثين)؛ "كتابة العلم" وساق فيه أربعة أحاديث.

- حديث علي رضي الله عنه عندما سئل: "هل عندكم كتـــاب؟ قـــال: لا، إلا

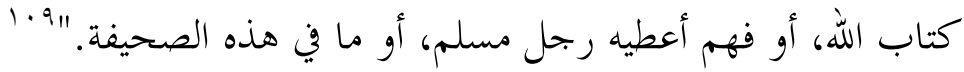

- حديث أبي هريرة رضي الله عنه في فتح مكة وفيه: "فجاء رجل من أهل اليمن

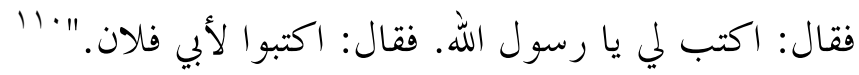

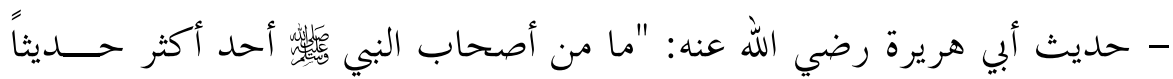

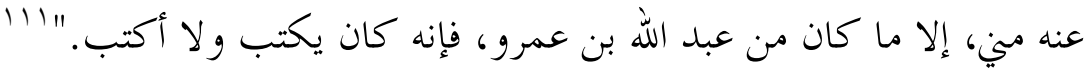

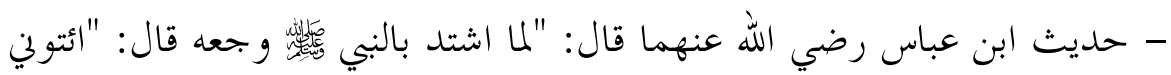

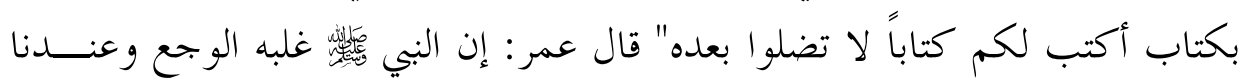

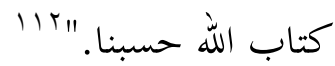

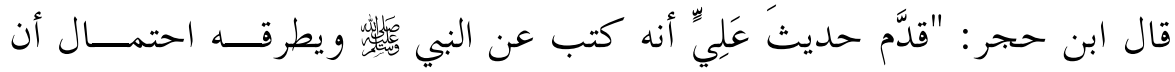

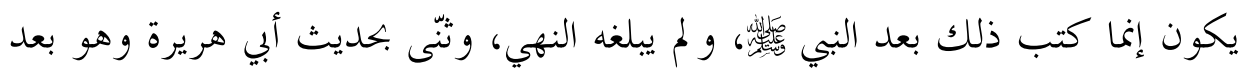

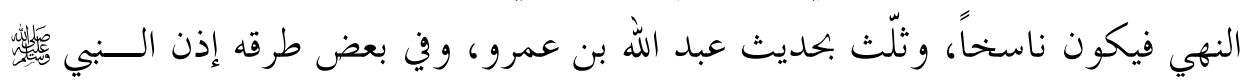

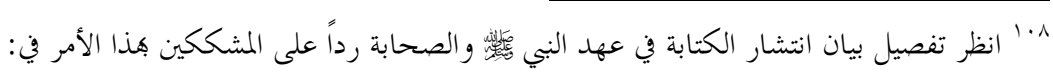

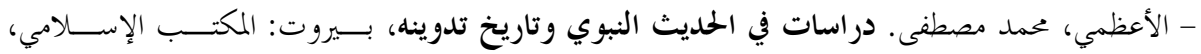

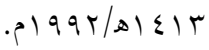

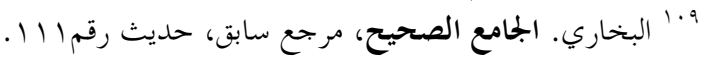

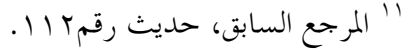

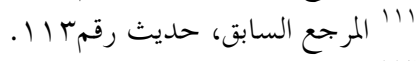

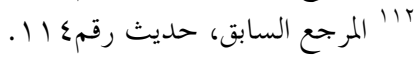




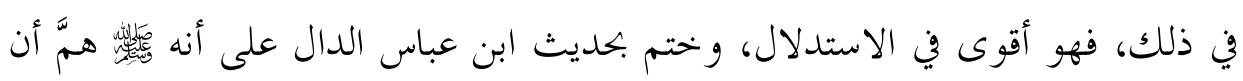

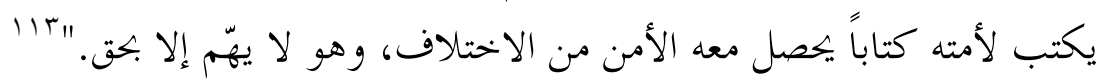

\section{ع. المصطلحات والمفاهيم التربوية الخاصة بالإمام البخاري:}

استعمل الإمام البخاري عدداً من المصطلحات و المفاهيم التربوية الــتي لم يُســـبق إليها، مما يدل على أصالة فكره التربوي وعمقه، ومن أهمها:

أ. العلم قبل القول و العمل: وهو ما جعله عنواناً (للباب العاشر). فكثير ممن كتب في الفكر التربوي الإسلامي يؤ كد تميز التربية الإسلامية عن غيرها بكوها تربية عملية.

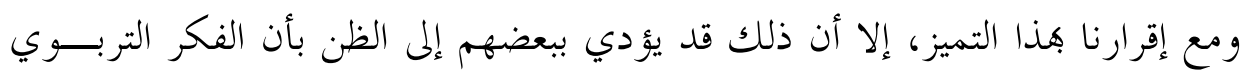

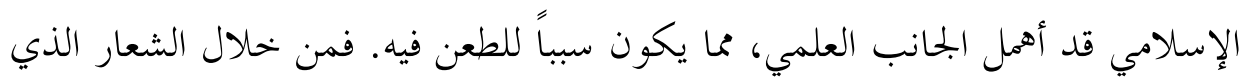

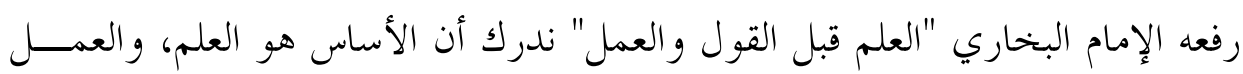

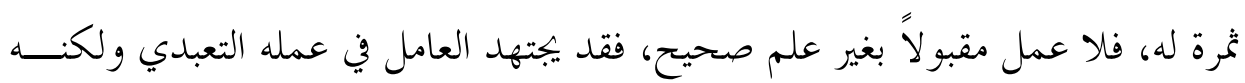

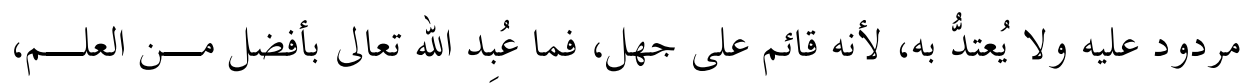

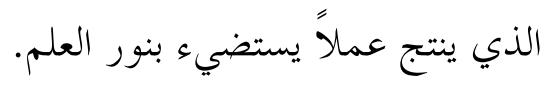

ب. الاغتباط العلمي: وورد ذكره عند البخاري في (البـــاب الخـــامس عشــر)؛

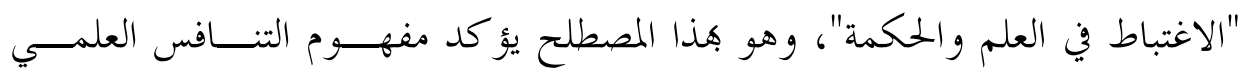
الشريف. فالمتعلم إذا علم أنه سيغبط بسبب علمه قوّى ذلك دافعيته للعلم، و حصل له

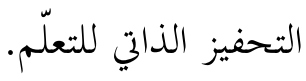

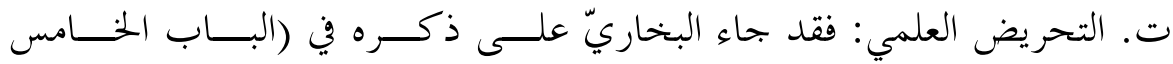

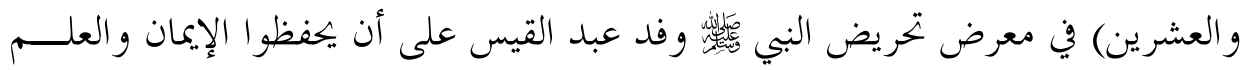

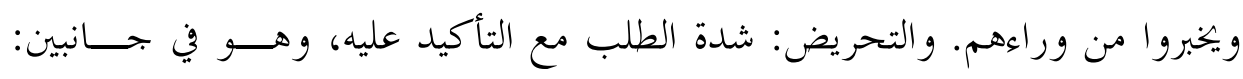
تحصيل العلم، و تبليغ العلم. 
ث. التناوب في العلم: ذُكر في (الباب السابع والعشرين)؛ وأورد فيه البخـــاري قصة تناوب عمر رضي الله عنه مع جاره الأنصاري في طلب العلم على يد رسول الله

ج. الغضب في التعليم: وقد ذكره البخاري في (الباب الثامن والعشرين)، بقوله: "الغضب في الموعظة و التعليم إذا رأي ما يكره".

و ونلحظ أن هذه المفاهيم والمصطلحات إنما استقاها البخهــاري مــن النصــوص

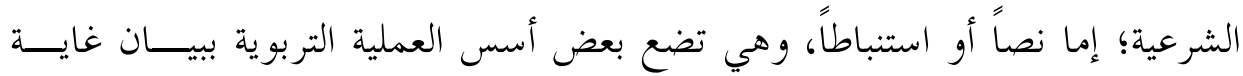

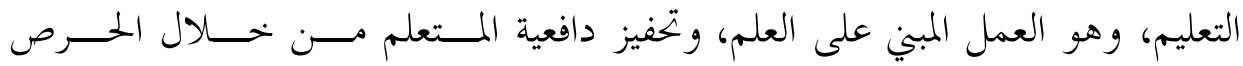
و التحريض على العلم، وأثر العلم في صاحبه بتحقيق الغبطة له، ودور المربي في توجيه المتعلم.

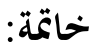

تبيّن لنا من النظر في الفكر التربوي لإمام البخاري كما عرضه هـــــا البحــــ،

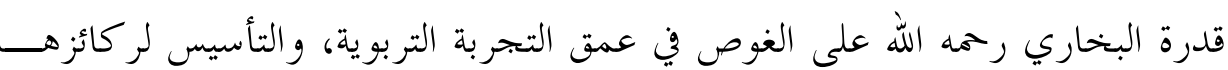

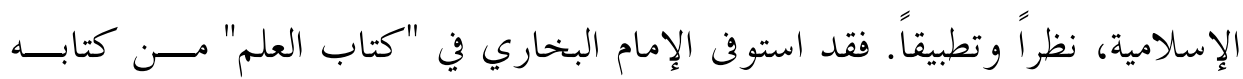

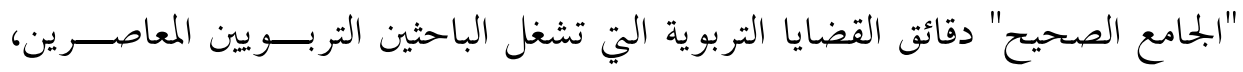

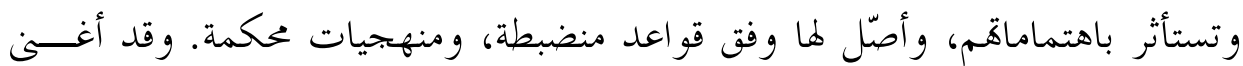
شرّاحُ الحديث النبوي نظرات البخاري التربويّة، و كشفوا عن شواردها كما فعل ابن حجر العسقلاني في شرحه لكتاب الجامع الصحيح.

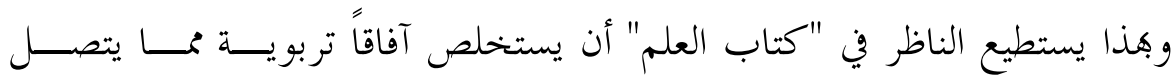

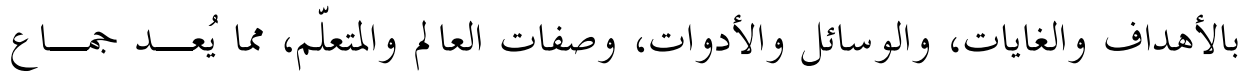
العملية التربوية. وخلص البحث إلى ضرورة إيلاء الجهود التربوية الإسلامية، العنايـــة

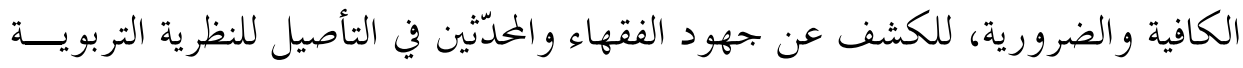
الإسلامية كما تتجلّى في السّنة النبوية. 